\title{
Studying the System of Monetary Sanctions
}

\author{
ALEXES HARRIS, MARY PATTILLO®, AND BRYAN L. SYKES
}

Monetary sanctions, also known as legal financial obligations (LFOs), are a highly consequential yet underexplored element of the criminal legal system. LFOs consist of fines, fees, costs, restitution, surcharges, and other financial penalties that are imposed on individuals when they encounter the criminal legal system. This contact can occur via traffic citation, or misdemeanor, juvenile, and felony conviction. Although indistinguishable for the people who are required to pay them, monetary sanctions are variably understood as punishments prescribed by state statutes and local codes, restitution for victims of crime, user fees to recoup system expenses or pay for services rendered, and additional charges for failure to pay. Most monetary sanctions are sentenced on conviction or citation, but some pretrial costs-such as jail booking fees, electronic monitoring, or public defender services in the absence of a conviction-can be passed on to defendants as well. ${ }^{1}$ These fines and fees are experienced as bills and debts for those on whom they are imposed and as revenue sources for the courts, agencies, jurisdictions, and states that collect them. Although the practice of imposing fines and fees on convicted persons has existed in law since the Magna Carta in 1215, research shows that the prevalence and amounts of monetary sanctions have grown over the last

Alexes Harris is Presidential Term Professor of Sociology at University of Washington, United States. Mary Pattillo is Harold Washington Professor of Sociology and African American Studies at Northwestern University, United States. Bryan L. Sykes is an Inclusive Excellence Term Chair, Chancellor's Fellow, and associate professor of criminology, law, and society at the University of California, Irvine, United States.

(C) 2022 Russell Sage Foundation. Harris, Alexes, Mary Pattillo, and Bryan Sykes. 2022. “Studying the System of Monetary Sanctions." RSF: The Russell Sage Foundation Journal of the Social Sciences 8(1): 1-33. DOI: 10.7758 /RSF.2022.8.1.01. This research was funded by a grant to the University of Washington from Arnold Ventures (Alexes Harris, PI). We thank the faculty and graduate student collaborators in the Multi-State Study of Monetary Sanctions for their intellectual contributions to the project. Partial support for this research came from a Eunice Kennedy Shriver National Institute of Child Health and Human Development research infrastructure grant, P2C HD042828, to the Center for Studies in Demography and Ecology at the University of Washington. Direct correspondence to: Alexes Harris, at yharris@uw.edu, Department of Sociology, Box 353340, University of Washington, Seattle, WA 98195-3340, United States.

Open Access Policy: RSF: The Russell Sage Foundation Journal of the Social Sciences is an open access journal. This article is published under a Creative Commons Attribution-NonCommercial-NoDerivs 3.0 Unported License.

1. Our study did not examine bail or bond practices, which are costs some people are able to pay to be released from jail prior to adjudication (see Scott-Hayward and Fradella 2019). Bail presents a somewhat unique case in that it is ostensibly refundable at the conclusion of a case. However, our research shows that at least a portion of sentenced fines and fees can be deducted from bail monies before refunding them, which makes bail a special prepaid form of monetary sanctions. 
five decades across federal, state, and local governments (Bannon, Nagrecha, and Diller 2010; Fergus 2018; Greenberg, Meredith, and Morse 2016; Harris, Evans, and Beckett 2010; Harris 2016; Shapiro 2014; U.S. Commission on Civil Rights 2017). ${ }^{2}$

The policy, legal, and social science literatures on monetary sanctions document critical features of this punishment schema (for an extensive review, see Martin et al. 2018; Martin 2020). Research shows that individuals struggle to pay their court debts, making it even more difficult to pay for essential expenses such as food, housing, health care, medicine, transportation, and childcare, thereby increasing stress (Harris, Evans, and Beckett 2010; Harris 2016; Pleggenkuhle 2018). This burden is not borne solely by those convicted of crimes but also by their family members and communities (deVuono-powell et al. 2015; Katzenstein and Waller 2015). Further, because people are not released from criminal legal supervision until their accounts are fully paid, monetary sanctions prolong supervision, make probation violations more likely, escalate sanctions for new criminal convictions, and result in incarceration for nonpayment (ACLU 2010; T. Atkinson 2016; Kohler-Hausmann 2018; Middlemass 2017; Western 2018). The racially disparate impact of monetary sanctions intensifies the aggressive policing of Black and Latinx neighborhoods because these groups typically find it more difficult to pay (Harris, Evans, and Beckett 2011; Henrichson et al. 2017; Henricks and Harvey 2017; Piquero and Jennings 2017; Sances and You 2017; U.S. Commission on Civil Rights 2017). The criminal legal monitoring and collection of fines, fees, and other costs extends and deepens the punishment of nonpayers and individuals reentering society, and warps the very legal institutions that legislate and implement these practices (Harris, Evans, and Beckett 2010, 2011; Harris 2016; Pattillo and Kirk 2021).

Yet, despite increasing attention to LFOs in criminal legal research and policy, the nascent literature on monetary sanctions has been limited in several ways. First, much of the research is limited to a few states or localities, potentially obscuring the full spectrum of knowledge regarding monetary sanctions across jurisdictions, and curtailing the possible insights from comparative analysis. Second, most studies focus on one component of LFOs, be it law, policy, practice, or people. Because the system of monetary sanctions includes all of these elements, such focused research can miss how law is experienced by those subjected to it, and how policies are transformed when put into practice. Third, data limitations have hampered inquiries into the distinct categories of LFOs and the demographic characteristics of those sentenced to them (Martin et al. 2018), complicating a full specification of the effects of LFOs. Last, few studies go deep into the institutions where monetary sanctions are legislated, imposed, managed, and collected, and hence obscure how legislatures, courts, and other agencies are embedded in the production and maintenance of the inequalities that build from criminal legal debt.

Drawing on data from a multimethod study of eight U.S. states, our project addresses these gaps in the literature and advances knowledge of monetary sanctions across a number of sociological, criminological, legal, and policy domains. The articles included in this volume represent a culmination of five years of work in California, Georgia, Illinois, Minnesota, Missouri, New York, Texas, and Washington State. ${ }^{3}$ Since 2015, we have examined each of these state's statutory codes; interviewed and surveyed individuals living under the weight of criminal legal debt; observed court practices and legal logics during pretrial, sentencing, and review hearings; collected administrative court data on the imposition of monetary sanctions over time; and interviewed and surveyed decision-makers and practitioners (judges, attorneys, probation officers, and clerks) about monetary sanctions. Our research team of more than eighty members included faculty and post docs, as well as graduate, undergraduate, and high school student research assistants (RAs). Faculty collaborators included

2. For a discussion of fines outside the United States, see Kantorowicz-Reznichenko and Faure 2021.

3. We are grateful to Arnold Ventures for providing the financial support that allowed us to conduct such a unique, expansive, and collaborative research project. 
Alexes Harris (University of Washington, the principal investigator, or PI), Beth Huebner (University of Missouri-St. Louis), Karin Martin (University of Washington), Mary Pattillo (Northwestern University), Becky Pettit (The University of Texas at Austin), Sarah K.S. Shannon (University of Georgia), Bryan L. Sykes (University of California, Irvine), and Christopher Uggen (University of Minnesota). To date, this is the only multistate, mixed-methods analysis indicating how states and local jurisdictions legislatively structure and legally impose and collect financial penalties in criminal and lower courts.

This volume investigates multiple facets of monetary sanctions. The articles present both within- and between-state analyses of racial disparities, geographic differences, homelessness, public assistance, emotional health and family experiences, parenthood, gender differences, economic inequality and disparate impacts, municipal courts, changes in law and practice, notions of accountability, and rural patterns of LFO revenue. Our research is both intensely local (such as Huebner and Giuffre's focus on Ferguson, Missouri) and broadly comparative (such as Harris's and Smith's examination of emotional health consequences across all eight states). Covering the spectrum from local to comparative is an important aspect of our research design because it facilitates discoveries about both deep institutional practices and systematic differences and commonalities across places.

Overall, our work has three main takeaways. First, we emphasize the importance of variation for both individual experiences and policy interventions. Second, monetary sanctions alone (aside from incarceration or a criminal conviction) generate a plethora of collateral consequences, which we conceptualize as "tentacles" that reach into the domains of immigration, housing, health, family, the labor market, public assistance, and more. Third, these tentacles inextricably link monetary sanctions to broader patterns of racial and economic subjugation and social control. ${ }^{4}$
RESEARCH ON MONETARY SANCTIONS Whereas other reviews of LFO research are organized along disciplinary lines or substantive foci (Martin et al. 2018; Martin 2020), we focus here on three periods of scholarship that have emerged in the study of the system of monetary sanctions, running roughly from 1980 to 2005, 2005 to 2013 , and 2014 to the present. The early set of studies began in the 1980s, and included a detailed report by Fahy Mullaney (1988) that described monetary sanctions across the country and emphasized their proliferation despite a notable absence from policy debates. In addition to fines, court costs, restitution (for property) and reparations (for harm), Mullaney enumerated twenty-three additional "service fees" (such as domestic offense education fee, urinalysis fee), five types of "special assessments" (such as late payment interest), and five "residual economic sanctions" (such as increased insurance rates after a driving under the influence conviction). Mullaney noted a fervent enthusiasm for economic sanctions among policymakers and practitioners, yet warned that monetary sanctions could produce and exacerbate inequalities.

Sally Hillsman and her colleagues similarly identified a growing attraction to the use of criminal fines in state courts as an "intermediate punishment" $(1988,16)$, between incarceration and impunity (Hillsman 1988; Hillsman and Greene 1992; Hillsman and Mahoney 1988; see also Gordon and Glaser 1991). In this early work, researchers focused on how courts could improve the efficiency of sentencing and collecting fines and fees. For example, in the late 1980s and early 1990s, a series of pilot projects assessed the viability of using day fines-financial sentences calibrated to the severity of an offense and a person's daily wage (Hillsman 1990; Hillsman and Greene 1992; McDonald, Greene, and Worzella 1992; Tonry and Lynch 1996). These interventions showed that meanstested sentencing schema were feasible and generated similar collection dollars as indiscriminate financial sentencing guidelines while offering relief to low-income defendants.

4. We use the term social control to reference the ways the criminal legal system, through the punishment of monetary sanctions, monitors, sanctions, and punishes people in order to regulate their behaviors (for a review related to monetary sanctions and the evolution of social control see Harris 2016). 
Barry Ruback and colleagues conducted some of the first multivariate analyses of monetary sanctions, studying both the context of sentencing LFOs and the experience of those being sentenced. In an analysis of case- and county-level characteristics associated with sentencing for restitution in Pennsylvania (Ruback, Shaffer, and Louge 2004), the authors find that property offenses and offenses against businesses were more likely to be charged restitution than other types of offenses, and that restitution was more likely to be charged and collected in counties with smaller populations. In a separate study using surveys with people owing penal debt (Ruback and Bergstrom 2006), Ruback and his colleagues found that many people could not make payments and did not know how much they owed or where their money went on payment.

Whereas the first period of relevant research called attention to monetary sanctions, the second period (2005-2013) explored a fuller range of financial penalties across a larger number of jurisdictions and began to examine consequences for affected individuals. For example, a 2008 report to the Washington State Minority and Justice Commission examined the case characteristics of individuals sentenced with fines and fees in Washington State and analyzed the consequences of monetary sanctions for people carrying criminal legal debt (Beckett, Harris, and Evans 2008). Other reports prepared by advocacy and practitioner organizations focused primarily on single states and documented the increased use of fines and fees, the large numbers of individuals incarcerated for nonpayment, and the counterproductive nature of revenue generation (ACLU 2010; Bannon, Nagrecha, and Diller 2010; Reynolds and Hall 2012; Rhode Island Family Life Center 2008; Rosenthal and Weissman 2007; TranLeung 2010). These policy reports were accompanied by growing social science interest in and theorizing about the relationship between monetary sanctions and inequality (Harris, Evans, and Beckett 2010, 2011).

A pivotal moment in raising national awareness of the system of monetary sanctions occurred in the aftermath of the August 2014 police killing of Michael Brown, an unarmed African American man from Ferguson, Mis- souri. The ArchCity Public Defenders released a report about municipal fines and fees in St. Louis County and the resulting criminal debt for residents (ArchCity Defenders 2014). The report prompted a more in-depth investigation by the U.S. Department of Justice (2015), and then a 238-page national study issued by the U.S. Commission on Civil Rights (2017). Together, these studies uncovered the increasing and excessive use of fines and fees in criminal courts, and the disproportionate burden on poor people and people of color.

Elaborating on the unequal racial and class contours of LFOs, A Pound of Flesh (Harris 2016) was the first book-length study to highlight the pernicious and permanent consequences for those who are saddled with criminal legal debt. It ushered in the third and current period of monetary sanctions research (2014-2021). A Pound of Flesh describes a punishment continuum, whereby counties across Washington State unevenly interpreted and applied laws regarding LFOs. Infused by decision-makers' personal values of personal responsibility, accountability, and redemption, and depending on the county where one was sentenced and monitored, individuals carrying legal debt faced punishments of varying intensity and duration.

Studies of monetary sanctions have grown significantly since 2015 to the present. Legal scholars, sociologists, political scientists, economists, and criminologists have produced a burgeoning body of scholarship. This work can be placed broadly into four categories: statutory and institutional contexts of monetary sanctions, additional costs and revenue generation for courts and locales, consequences of LFOs for individuals and institutions, and theoretical and legal analyses of monetary sanctions.

Studies of the statutory and institutional contexts of monetary sanctions illustrate that it is a system of legal statutes, administrative policies, and court procedures that facilitates the imposition, collection, and distribution of financial resources assessed to criminal defendants at the time of sentencing. In interviews with judges in North Carolina, Gene Nichol finds that judges complain about limited discretion because the legislature has "bullied" them into imposing monetary sanctions by 
mandating that they justify any decisions to waive fees $(2020,228)$. Brittany Friedman and Mary Pattillo (2019) describe the system in Illinois as "statutory inequality," whereby penal indebtedness for poor people is inscribed in law on the books. In the juvenile realm, Leslie Paik and her colleague (Paik and Packard 2019; Paik 2020) map the types and amounts of LFOs juvenile courts impose on the guardians of minors, and challenge the primary tropes of restitution as a means by which youth can repair harm and show responsibility. In misdemeanor and traffic courts, scholars explicate the role that LFOs play in expanding state control of an ever-larger number of people (Natapoff 2018; Kohler-Hausmann 2018; Martin et al. 2018; Needham, Mackall, and Pettit 2020; Slavinski and Pettit 2021).

A second body of contemporary scholarship moves outside the legislatures and courtrooms and looks at the additional financial costs associated with other types of sentences, such as community service, offenses related to substance use disorders, and other unfunded mandates imposed on defendants at the time of sentencing (Herrera et al. 2019; O'Neil and Strellman 2020; Harris, Smith, and Obara 2019). Scholars frame these extra costs-and the revenues officials generate from contracts with third-party entities-as "prison retailing" and "kickbacks" (Raher 2020, 5; Katzenstein, Bennett, and Swanson 2020, 259). A recent report relying on data from just twenty-five states approximates that in total \$27.6 billion is owed in monetary sanctions (Hammons 2021). Given the mandatory nature of these fines, fees, and costs, Mary Katzenstein and Maureen Waller $(2015,639)$ describe the "seizure" of resources from systeminvolved individuals and their families, a process that is more intense in municipalities with higher proportions of Black residents (Sances and You 2017). Considerable research has documented the revenue-generating intentions of LFOs (Mai and Rafael 2020), often with little to show in the way of actual collections, improved policing, or increased municipal services (Crowley, Menendez, and Eisen 2020; Edwards 2020; Goldstein, Sances, and You 2020; Henricks and Harvey 2017; Kirk, Fernandes, and Friedman 2020; Fernandes et al. 2019; Pacewicz and Robinson 2020).
A third body of contemporary scholarship examines the consequences associated with imposing monetary sanctions at both the individual and institutional levels. At the individual level, some studies broadly characterize who is sentenced to pay LFOs (Link 2019), and others focus on specific consequences of LFOs, such as recidivism, the loss of driver's licenses, and voting restrictions (Bender et al. 2015; Colgan 2019; Garrett, Modjadidi, and Crozier 2020; Sebastian 2020; Piquero and Jennings 2017; Uggen et al. 2020). The LFOs that accrue from criminal traffic cases can be especially sticky, leading to new cases of driving on a suspended license, and even incarceration, especially for Black drivers (Edwards and Harris 2020). This body of work also moves beyond identifying the individual-level consequences of debt to show how insurmountable debt and its aggressive collection can lead to the delegitimization of the U.S. criminal legal system and its representatives (Brett 2020; Cadigan and Kirk 2020; Link et al. 2021; Pattillo and Kirk 2020; Ruhland, Holmes, and Petkus 2020; Shannon et al. 2020). Emergent scholarship examines the neighborhood-level consequences for communities of color characterized by high rates of criminal legal debt and poverty (O'Neill, Kennedy, and Harris forthcoming).

A fourth and final line of inquiry in the contemporary literature covers theoretical and legal perspectives on the system of monetary sanctions. Some notable examples include Beth Colgan's $(2017,2018,2019)$ examination of the extent to which the long-term debt to which people are sentenced could be viewed as violating the excessive fines and fees clause of the Eighth Amendment to the U.S. Constitution. Torie Atkinson (2016) uses both legal reasoning and empirical analysis to examine the nonsensical practice of municipal fines, which are claimed to be an alternative to incarceration, but in reality the fines coupled with additional fees, payment charges, and other costs, lead poor people to jail. In a similar way, Abbye Atkinson (2017) uses legal reasoning to show the arbitrariness of states' failure to provide relief from penal debt that is disproportionately borne by people of color and the poor. Atkinson's analysis raises interesting questions about who "deserves" debt relief and who does 
not. Scholars have also theorized about the system of monetary sanctions as predatory (Harris 2020; Page and Soss 2017; Page, Piehowski, and Soss 2019), unjust (Shannon 2020), and coercive (Pattillo and Kirk 2021).

\section{THE SHIFTING POLICY LANDSCAPE}

As noted, the practice of imposing fines at sentencing dates to the Magna Carta. In recent decades, the scale, prevalence, distribution, and types of monetary sanctions have evolved into a web-like structure that adds costs, fees, surcharges, penalties, and interest. Yet, in response to both the growth in research highlighting the negative consequences of monetary sanctions and the federal level attention to LFOs, new reforms have emerged.

Recently, several states and local jurisdictions have begun revising local policies and state statutes governing the sentencing and collection of monetary sanctions and related punishments. In general, the policy changes have stipulated the extent to which jurisdictions can rely on revenue generated from fines and fees, provided relief for indigent individuals at or after sentencing, eliminated certain types of discretionary fines and fees, and discontinued suspending or revoking driver's licenses related to failure to pay traffic or other court costs.

One of the first set of statewide reforms occurred in 2015 when the Missouri state legislature amended Mack's Creek Law, originally passed in $1999,{ }^{5}$ to limit the percentage of a jurisdictions' annual general operating revenue from traffic citations to 20 percent. ${ }^{6}$ In 2016 , a more comprehensive bill centered individuals' procedural rights regarding municipal violations. This legislation required indigence stan- dards in sentencing, alternative sanctions including community service, and payment plans. The bill also capped fine and fee amounts, forbade judges from serving in any other legal capacity in the same jurisdiction, and prohibited jail for failure to pay. ${ }^{7}$ Along similar lines, in 2018, the Washington State legislature prohibited judges from imposing discretionary fines or fees on defendants if they were indigent, homeless, or mentally ill. ${ }^{8}$ In 2020, Seattle Municipal Court judges moved to discontinue imposing discretionary costs in criminal cases. ${ }^{9}$ Similarly, in the same year, the California legislature enacted changes to eliminate twenty-three criminal legal fees including costs related to probation and mandatory supervision, public defense, processing for arrests and citations, home detention, electronic home monitoring, and work furlough and release. ${ }^{10}$

In 2018, California abolished all administrative fees imposed in juvenile delinquency cases. Other jurisdictions, such as Orleans Parish in Louisiana and the states of Nevada, New Jersey, and Maryland all limited or abolished juvenile civil fines and court costs, as well as limited fiscal charges to parents and guardians. The Los Angeles County Board of Supervisors went one step further in 2018 and stopped collecting on unpaid juvenile penal debt, which discharged over \$89 million in debt.

In many jurisdictions, unpaid parking tickets and court fines and fees can lead to driver's license suspension or revocation, with negative consequences for employment and family responsibilities. Illinois, Virginia, California, New York, and Texas, among other states, have taken various steps to stop or curtail these prac-

5. See Revised Statutes of Missouri (RSM0) 2000, § 302.341.2. Effective August 2013.

6. Missouri Senate Bill (MO SB) 5, https://www.senate.mo.gov/15info/BTS_Web/Bill.aspx?SessionType=R\& BillID=160.

7. MO SB 572, https://www.senate.mo.gov/16info/pdf-bill/tat/SB572.pdf (accessed July 24, 2021).

8. WA State HB 1783, https://app.leg.wa.gov/billsummary?BillNumber=1783\&Year=2017 (accessed July 24, 2021).

9. Daniel Beekman, "Seattle Municipal Court has stopped charging fees for probation in criminal cases," September 23, 2020, https://www.seattletimes.com/seattle-news/politics/seattle-municipal-court-has-stopped -charging-fees-for-probation-in-criminal-cases (accessed July 24, 2021).

10. CA AB1869, https://leginfo.legislature.ca.gov/faces/billTextClient.xhtml?bill_id=201920200AB1869. 
tices. ${ }^{11}$ Virginia's 2019 law is retroactive, reinstating suspended driver's licenses and waiving fees for cases prior to the bill's enactment. ${ }^{12}$ In 2021, the Illinois legislature stopped suspending driver's licenses for unpaid automated speed and red light camera tickets..$^{13}$ Also in 2021, New York's governor signed the Driver's License Suspension Reform Act, which ended suspension for unpaid traffic tickets and mandated income-based payments. ${ }^{14}$ Similarly, the Texas legislature repealed the Driver Responsibility Program, under which 1.4 million Texans had suspended driver's licenses. ${ }^{15}$ When states have not gone far enough, cities have stepped in. The City of San Francisco reinstated some licenses for people who failed to appear in court related to traffic citations.

In addition to policy and statutory reforms, courts are reconsidering ability-to-pay standards and the proportionality of LFOs. In Washington v. Blazina, the Washington State Supreme Court established a requirement that sentencing judges hold an ability-to-pay hearing to first assess defendants' current income net of household expenses (such as childcare, housing, food and medical needs) prior to imposing monetary sanctions. ${ }^{16}$ In contrast, other state courts decided not to provide such protections. For example, in Georgia State Conference of the NAACP $v$. City of LaGrange, the lower court found that people must pay all their fines and fees assessed by the LaGrange City Municipal Court before they can gain access to the city's utility services. ${ }^{17}$ These costs can include municipal court fines and fees unrelated to utility services.

Florida's debate about monetary sanctions and voting has also prompted court review (for analysis, see Morse 2021). A successful 2018 ballot referendum in the state restored the right to vote to most "Floridians with felony convictions after they complete all terms of their sentence including parole or probation" ${ }^{18}$ The Florida legislature, however, interpreted "all terms of their sentence" to include monetary sanctions, an interpretation that was upheld in Jones $v$. Governor of Florida by the 11th U.S. Circuit Court of Appeals in September 2020. ${ }^{19}$ Christopher Uggen and his coauthors (2020) estimate that this restriction excluded approximately nine hundred thousand Floridians from voting in the 2020 presidential elections.

The U.S. Supreme Court recently decided a pivotal case regarding monetary sanctions in Timbs $v$. Indiana. ${ }^{20}$ Tyson Timbs had been arrested for allegedly dealing drugs and conspiracy to commit theft. On his arrest, the police seized Timbs's SUV, which he had purchased with $\$ 42,000$ from an inheritance. Given that the cost of the vehicle was more than four times the maximum fine $(\$ 10,000)$ for the offense,

11. "Public Safety," in California State Budget: 2017-18, 29, http://www.ebudget.ca.gov/2017-18/pdf/Enacted /BudgetSummary/PublicSafety.pdf (accessed July 24, 2021).

12. Virginia Senate Bill (VA SB) 1, https://lis.virginia.gov/cgi-bin/legp604.exe?201+sum+SB1.

13. Illinois House Bill (IL HB) 3653 (effective January 1, 2022), https://www.ilga.gov/legislation/101/HB/PDF /10100HB3653lv.pdf.

14. NY A7463B, https://www.nysenate.gov/legislation/bills/2019/a7463.

15. TX HB 2048, https://legiscan.com/TX/text/HB2048/2019.

16. State of Washington v. Blazina, 344 P.3d 680 (Wash. Supreme Court 2015).

17. Georgia State Conference of the NAACP v. City of LaGrange, 940 F.3d 627 (11th Cir. 2019).

18. Florida Amendment 4. 2018. “Voting Rights Restoration for Felons Initiative." Florida Association of Counties. https://www.fl-counties.com/amendment-4.

19. Jones v. Governor of Florida, 975 F.3d 1016 (11th Cir. 2020).

20. Timbs v. Indiana, 139 S. Ct. 682 (2019). For a full review and discussion see Colgan and McLean 2020. Several members of our research team contributed to an amicus curiae for the Timbs case to detail the punishment schema of monetary sanctions and the related negative consequences for those who are unable to pay. See Timbs v. Indiana, Brief amicus curiae, May 5, 2018, https://www.supremecourt.gov/DocketPDF/17/17-1091/37558 /20180305114204540_17-1091\%20Amici\%20Brief\%20Professors.pdf (accessed July 24, 2021). 
Timbs's lawyers argued that the punishment was disproportionate given the gravity of the offense. The Supreme Court sided with Timbs, concluding that the forfeiture was unconstitutional under the Eighth Amendment's Excessive Fines Clause. The late Justice Ginsburg wrote that monetary sanctions should be "proportioned to the wrong" and "not be so large as to deprive [a person] of his livelihood." ${ }^{21}$ She referenced the nineteenth-century creation and use of Black Codes to convict, fine, and "subjugate newly freed slaves and maintain the prewar racial hierarchy." Further, she concluded that "For good reason, the protection against excessive fines has been a constant shield throughout Anglo-American history" (2019, 5-6).

Despite the difficulties entailed in dismantling multiple layers of monetary sanctions and the related social, fiscal, and political consequences, advocacy, legal, and policy organizations are mounting a robust attack on LFOs as economically regressive, racially disparate, and overwhelmingly devastating (Highsmith 2020; Fines and Fees Justice Center 2020; Berkeley Law 2019; Criminal Justice Policy Program 2016). The legal landscape we were studying shifted under our feet as we observed courtrooms, interviewed stakeholders, and conducted our analyses. ${ }^{22}$ However, engaged immersion in the field meant that our developing research findings informed many legal and policy discussions, and observed shifts in policies also became focal objects of social scientific inquiry (see Smith, Thompson, and Cadigan 2022, this volume).

\section{THE MULTI-STATE STUDY OF MONETARY SANCTIONS}

The Multi-State Study of Monetary Sanctions grew out of the first and second eras of scholarship in the study of fines and fees in the U.S. criminal legal system, and our analyses have, in part, shaped and contributed to the current line of inquiry (Harris et al. 2018). Our research aim was to move beyond one jurisdiction or one part of the system of monetary sanctions to construct a dataset that was fully integrated (Seawright 2016). The guiding research questions were, "how does the system of monetary sanctions operate across states, and what similarities and differences exist in policies, practices, implementation, and consequences across and within the states?"

Monetary sanctions are legislated and imposed across all levels of government, calling into question whether a "representative" state or jurisdiction is even possible. The thousands of villages, cities, and counties-across all fifty states and the District of Columbia-have intertwined distinct laws and rules regarding LFOs. The legal, administrative, in-depth interview, survey, and ethnographic data collected in the eight states enable us to explore differences across and within jurisdictions, and our multi-actor interviews and surveys yield information about how stakeholders approach, view, experience, resist, and accommodate LFOs. Finally, our use of qualitative and quantitative data produces a thick knowledge about emotions, bodily experiences, personal histories, and court evaluations and a statistically robust understanding of patterns, disparities, correlations, and trends in relation to monetary sanctions.

\section{Research Sites and Selection}

Our aim is to be painstakingly transparent about our analytic strategies, realities, and methodologies as we collected and processed the data. Our description of the process is a result of a dizzying number of meetings, conference and Zoom calls, compromises, shared documents, second-guessing, training videos, trial-and-error decisions, negotiations, background readings, team building exercises, mutual encouragement, and deadlines, deadlines, deadlines. While Alexes Harris shaped the general study framework, the implementation of her vision was maximally iterative, deliberative,

21. Quoting Justice Ginsburg in reference to Browning-Ferris, 492 U.S., at 271. (Timbs v. Indiana, 139 S. Ct. 682 (2019).

22. The Fines and Fees Justice Center provides an updated clearinghouse of legislative and policy developments. See "The Clearinghouse," https://finesandfeesjusticecenter.org/clearinghouse/?sortByDate=true (accessed July 24, 2021). 
and collaborative among all team members, regardless of institutional status, academic rank, or disciplinary focus.

The eight states included in the Multi-State Study of Monetary Sanctions were chosen to maximize heterogeneity in population size, demographics (by race, poverty, and immigration), political partisanship, region, and criminal legal policy and practice. The eight states represent roughly 36 percent of the U.S. population, are located on both coasts, in the South, and in the Midwest, and run their legal systems in very different ways: Missouri has municipal courts but Illinois does not; Georgia has private probation, but Washington State does not. More than 30 percent of the adult prison and jail population and more than 40 percent of people on community supervision lived in these eight states in 2014. Brittany Friedman and her coauthors (this volume) elaborate on the diversity of criminal legal regimes in these states as well as how legal financial obligations feed their revenue streams. Their analysis confirms that our selection of states captured significant heterogeneity in systems of incarceration, probation, and monetary sanctions, allowing us to build comprehensive empirical conclusions and policy recommendations through our comparative analysis.

At the same time, geographic specificity is also key. Fines and fees are authorized in state and local (county, village, city) statutes and imposed in criminal and traffic courts located within substate jurisdictions. The original research design called for each state research team to identify three counties and three cities for focused legal review and qualitative data collection. This plan immediately highlighted the heterogeneity in court structures across states and the impossibility of aligning site selections. For example, California, like Illinois, moved away from a three-tiered system to a unified court structure that governs the imposition of monetary sanctions by state (not county or local) laws. Yet, in California (like Washington), each county court is its own superior court, whereas in Illinois county courts are components of multicounty circuit courts. County courts in Illinois hear traffic, misdemeanor, and felony cases. Illinois's court system contrasts with Georgia's five-tiered judiciary sys- tem. Misdemeanor and traffic cases without juries can be heard in either municipal or county courts, whereas felony cases and jury trials are always administered at the county level. Meanwhile, in New York, courts of original instance include supreme courts, county courts, district courts, New York City criminal courts, and city, town, and village courts. In other words, whereas cities are relevant court locations in New York and Georgia, they are not in California and Illinois. This ostensibly simple exercise of establishing a research design offers important insight into the challenges of studying, and thus intervening in and possibly reforming, any criminal legal processes, including the system of monetary sanctions.

\section{Data Collection}

The Multi-State Study of Monetary Sanctions was a five-year multimethod project that began in the fall of 2015. Each academic year was dedicated to a discrete aspect of data collection and analysis.

\section{Year 1: Legal Review}

The first step in the research involved understanding the legal landscape in each state and the legislative foundations for LFOs. These legal reviews helped us understand how widely our states varied in court structure and nomenclature. Each state team gathered topic-specific information, such as the number of jurisdictions contained within higher-order court units; the relationships between higher and lower courts (where relevant); demographic, historical, or political nuances that affected court administration; and the roles and responsibilities of various court actors in imposing, monitoring, and collecting monetary sanctions.

The core part of this endeavor was the creation of detailed databases of the statutes pertaining to criminal fines, fees, and other monetary penalties at the state level as well as for the sampled counties and cities. Statutes were readily accessible through public online interfaces that local and state governments maintained and updated. Creating the LFO databases entailed searching these repositories for the words fines, fees, surcharges, costs, and penalties and other financial terminology. Although some state research teams compiled 
information on civil fines and fees, the project focused on LFOs attached to criminal infractions, from traffic cases to major felonies. ${ }^{23}$

Statutes governing legal financial obligations are not confined to state criminal codes. In some states, we needed to read across statutory domains (such as health laws and education laws) to discover the full range of legislation governing LFOs. In other states, codes governing LFOs were more neatly contained within the criminal code. Once a statute or administrative rule was identified, it was coded for up to twenty characteristics, such as whether nonpayment triggered license suspension, whether it was eligible for referral to private collections, or whether interest accrued after the due date. Basic information included the statute number, where it appeared in the state code, whether it was a fine or a fee, the year it was passed, whether it was mandatory or discretionary, and either the full text or a summary of the statute itself. We undertook the same process for county and municipal codes within selected jurisdictions to document how local laws relate to state systems of LFOs. This exercise yielded eight state-level spreadsheets with individual statutes and substatutes along with their relevant characteristics.

The second task of the legal review involved a careful reading of legal cases within each state that challenged the imposition and enforcement of monetary sanctions. Within our respective states, several foundational Supreme Court cases establish, or affirm, the importance of due process and equal protection for persons assessed legal financial obligations. Williams $v$. Illinois and Tate v. Short, originating in Texas, established that a fine could not be converted to jail time solely because the defendant was too poor to pay. Bearden v. Georgia held that individuals could not be incarcerated for nonpayment of a fine or restitution without the privilege of a hearing to determine if nonpayment was "willful," that is, that they had the means but still did not pay. ${ }^{24}$ These Supreme Court rulings resulted from cases filed at the local and state levels. We conducted reviews and summaries of such lower court cases in the contemporary period within the eight states. The articles making up section 1 of issue 1 draw heavily from the data collected through these various components of the legal review in Year 1.

\section{Year 2: Qualitative Interviews and Surveys with} Individuals Sentenced to Pay LFOs

Across the eight states, we interviewed and surveyed 519 individuals who had been ordered to pay monetary sanctions. Our goal was to capture respondents' experiences, both inside the courtroom and as they managed financial obligations in their daily lives. The target number of interviews was sixty per state. We reached or exceeded that number in all states except New York, where we conducted fifty-nine (table 1). This part of the study - along with the in-depth interviews and surveys of court actors-was approved by the Institutional Review Board (IRB) of the University of Washington (with federalscale assurances for the University of CaliforniaIrvine and the University of Georgia, under UW's IRB) as well as the IRBs at the other collaborating universities.

We interviewed individuals in each state who were currently paying their LFOs and a limited number of those who had already paid in full. The interview sample was diverse by jurisdiction (county or municipality) and offense type (felony, misdemeanor, traffic). We used a range of recruitment strategies. We posted fliers at relevant community organizations (such as YMCAs, legal clinics, and reentry service providers), in courthouses, in public defenders' offices, and in probation and parole offices, if allowable under IRB guidelines. We also advertised on public websites, such as Craigslist. We recruited directly in community supervision offices and following court hearings. Interviewees were paid \$15 for participating.

23. Anjuli Verma and Bryan Sykes (2022, this volume), however, document how the codification and coding of California state statutes have blurred the distinction between civil and criminal monetary sanctions associated with punishment because civil code violations can result in criminal charges that impose mandatory monetary sanctions.

24. Williams v. Illinois, 339 U.S. 235 (1970); Tate v. Short, 401 U.S. 395 (1971); Bearden v. Georgia, 461 U.S. 660 (1983). 
Table 1. Court-Involved Interview and Survey Sample

\begin{tabular}{lc}
\hline State & N \\
\hline California & 60 \\
Georgia & 60 \\
Illinois & 68 \\
Minnesota & 70 \\
Missouri & 80 \\
New York & 59 \\
Texas & 62 \\
Washington & 60 \\
Total & 519 \\
\hline
\end{tabular}

Source: Authors' tabulation.

Interviews were conducted in respondents' homes, coffee shops, public parks, libraries, probation offices, and even at bus stops and lasted between fifteen and ninety minutes, the target duration being forty-five minutes. The interview encounter included administering the survey. Interviewers later entered responses to the closed-ended survey questions into an online password-protected interface in Qualtrics. Interview audio was uploaded to the research team's central server. The interviews were professionally transcribed and checked for completeness and quality.

We present the interview guides for people with criminal justice debt, as well as the interview guides for judges, in online appendices $\mathrm{A}$ and $\mathrm{B}$, respectively. ${ }^{25}$ The survey consisted of forty-six questions covering a respondent's convicted offense or offenses, incarceration, LFO amounts and payment history, gender, age, race, education, income, employment, family, housing situation, and use of public benefits, among other topics. The qualitative interview guide included thirteen questions designed to foster open-ended conversation. A crucial miscommunication in Year 2 resulted in state research teams commencing interviews at different points in the year, such that some states began with survey and interview guides that were not yet final. For example, early versions of the survey included no questions about homelessness, housing tenure, or health insurance, but did ask about different types of incarceration. However, after final collection of the data, the survey responses from both guides were analytically mapped onto the same response items. Once the project was in full swing, we also experienced variation in rapport with respondents, which led to some questions going unasked or unanswered, as well as unevenness in how teams entered data into the Qualtrics survey software. We discuss this learning curve more fully in our account of Year 5.

\section{Year 3: Qualitative Interviews and Surveys with} Court Actors and Courtroom Ethnographies

By Year 3, the site research teams were more familiar with the landscape of the courts and LFOs in their states such that undertaking two modes of data collection was somewhat more feasible. Across the eight states, we conducted interviews and surveys with 447 court actors to understand their practices and perspectives, and did more than 1,900 hours of courtroom ethnography to document firsthand how LFOs are sentenced, discussed, and monitored in real time. ${ }^{26}$ Court actors (or decision-makers) included judges, prosecutors, defense attorneys, probation or community corrections officers, and court clerks.

We solicited interviews by embedding ourselves in court buildings over a period of weeks or months (or years, in some cases) to develop familiarity and rapport. We approached court personnel during breaks or after court. We also sent cold emails requesting interviews and asked for referrals upon completing inter-

25. The online appendix is available online under supplemental materials on the article's RSF homepage.. The item response numbering shown in the survey/interview instrument for both the court-involved respondents (appendix A) and judges (appendix B) does not correspond to the final coding scheme for managing and analyzing the survey data.

26. The Missouri team interviewed a bail official and the Texas team interviewed a court bailiff. These categories of court actors were not included in the research design, so we do not include them in the total number of 447 interviews. Also, two interviews lacked transcripts because they were not recorded and two interviews were transcribed but not coded. Because of these issues, authors' tallies of court actors for all eight states vary from 443 to 449 depending on the topic and specific data being analyzed. 
Table 2. Court Actor Interviews Conducted in Eight States

\begin{tabular}{lcccccc}
\hline & Judge & Prosecutor & $\begin{array}{c}\text { Defense } \\
\text { Attorney }\end{array}$ & $\begin{array}{c}\text { Probation } \\
\text { Officer }\end{array}$ & Clerk & $\begin{array}{c}\text { Total } \\
\text { by state }\end{array}$ \\
\hline California & 18 & 6 & 22 & 4 & 3 & 53 \\
Georgia & 16 & 6 & 10 & 11 & 7 & 50 \\
Illinois & 28 & 18 & 20 & 8 & 13 & 87 \\
Minnesota & 11 & 17 & 21 & 9 & 6 & 64 \\
Missouri & 14 & 4 & 8 & 12 & 8 & 46 \\
New York & 12 & 4 & 19 & 0 & 9 & 44 \\
Texas & 17 & 18 & 15 & 4 & 11 & 65 \\
Washington & 9 & 9 & 15 & 2 & 3 & 38 \\
Total by category & 125 & 82 & 130 & 50 & 60 & 447 \\
\hline
\end{tabular}

Source: Authors' tabulation.

views. Interviews lasted roughly an hour and took place across a range of locations, such as judges' chambers, public defenders' offices, court cafeterias, libraries, and local coffee shops. Court actors were not paid for participating.

Variation was considerable across states in access to court actors, as shown in table 2 . We aimed to interview twenty-eight judges, eighteen prosecutors, eighteen defense attorneys, eight probation officers, and twelve clerks in each state for a total of eighty-four interviews per state. Probation officers and their managers in New York refused to be interviewed. The research team in Washington was told it could not interview probation officers without undergoing a $\$ 3,000$ state-level institutional review board process. Most research teams did not face such concrete barriers or outright rejection, but did encounter court actors' lack of time (often reflecting case overloads), distrust of researchers, concerns about public opinion, and other such reasons that are not uncommon when studying elites (Aguiar and Schneider 2016). Because of this differential access, the total number of decision-maker interviews across states ranged from thirty-eight in Washington to eighty-seven in Illinois.

All state teams used the same protocol, which consisted of a short survey and an openended interview guide. Given their distinct courtroom roles and relationships to the system of monetary sanctions, not all court actors were administered the same instrument. For example, questions about issuing warrants or using bench cards that were asked of judges were not appropriate for other court actors. Similarly, we asked only court clerks how frequently unpaid fines and fees were sent to private collection agencies. Online appendices C and $\mathrm{D}$ show examples of the survey protocols for people with criminal justice debt and judges, respectively. The survey of justice involved people consisted of forty-six questions, and the survey of judges included twenty-five questions about general court practices (such as how often LFOs are imposed, average amounts, frequency of granting waivers). Both survey protocols captured interviewee demographic information, including gender, race, age, and length of employment in their roles. The qualitative component of the interview helped guide an open-ended discussion in which court actors narrated how LFOs worked in their courtrooms and jurisdictions, shared details regarding amounts and ranges of LFOs, discussed the impact of LFOs on defendants and court functioning, and related their personal views and discussions with colleagues about LFOs. Researchers later entered responses to the closed-ended survey questions into a spreadsheet. Interview audio was uploaded to the research team's central secure server. The interviews were professionally transcribed and checked for completeness and quality.

As we were interviewing court actors, we were also observing their courtrooms. This was not a perfect overlap; we interviewed court actors we did not observe and we observed courtrooms without interviewing any of the person- 
Table 3. Data Gathered through Courtroom Ethnographies

\begin{tabular}{lccc}
\hline State & $\begin{array}{c}\text { Observation } \\
\text { Hours }\end{array}$ & $\begin{array}{c}\text { Number of } \\
\text { Cases Logged }\end{array}$ & $\begin{array}{c}\text { Pages of } \\
\text { Field Notes }\end{array}$ \\
\hline California & 319 & 759 & 76 \\
Georgia & 240 & 772 & 90 \\
Illinois & 241 & 2,036 & 117 \\
Minnesota & 207 & 676 & 36 \\
Missouri & 222 & 772 & 93 \\
New York & 252 & 2,240 & 42 \\
Texas & 282 & no data & 106 \\
Washington & 169 & 2,928 & 130 \\
Totals & 1,932 & 10,183 & 690 \\
\hline
\end{tabular}

Source: Authors' tabulation.

nel. Spending hours observing a courtroom often provided the necessary familiarity to approach court actors for interviews. Courtroom ethnographies were guided by a standardized observation log sheet and template for writing field notes. Gathering real-time data in courtrooms is extremely challenging. Cases could be as short as fifteen seconds, leaving the observer little time to record information on the observation protocol before the next case commenced. Judges often spoke too quietly for observers to hear, especially as other people in the gallery shuffled, whispered, or grumbled. What had been a plan of methodical documentation on a standardized courtroom observation sheet turned into straining to hear, repositioning in the courtroom, and feverish notetaking.

Following observations, researchers entered as much objective information about the cases they observed as possible into a standardized spreadsheet. In some states and jurisdictions, they supplemented observations with information from online case searches. The full list of variables captured on the courtroom observation spreadsheets includes observer name, date, case start and end time (for cases lasting more than two minutes), county or city, courtroom number, court type (traffic, misdemeanor, felony), case id, offense or charge, type of proceeding (such as plea, hearing, sentencing, continuation), defendant gender, race, age, criminal history, status (in custody or not), judge name, prosecutor name or other characteristics, defense attorney name and type (public or private), court clerk name or other char- acteristics, court security (how many), fine amount, fees, restitution, surcharges, other LFO amounts, any payment terms, probation or supervision length or terms, jail or prison sentence and length, additional sentence (such as community service), financial penalties discussed (yes or no), and English translator present.

Table 3 shows the total numbers of observation hours, cases logged, and fieldnote pages in each state. The goal was 240 hours of courtroom observations in each state, which we achieved in five of the eight. Variations in the number of cases logged reflect decisions about documenting even the shortest individual cases; it was not uncommon for a case to consist of nothing more than announcing the docket number, calling up the defendant, and swiftly issuing a continuance. Whereas in some states researchers included even these encounters on their spreadsheets, others decided to record only cases with more substantive discussion. Clearer instructions and coordination at the outset may have made the data more comparable across states. Some state research teams also faced staffing constraints. Whereas some teams included a principal investigator and several undergraduate and graduate research assistants - assembled through combinations of separate research funds, unpaid opportunities, or university research mentoring programs - other teams had just a PI and one research assistant. Team Washington's PI unfortunately took medical leave for a year (20162017). Despite these particularities, this effort 
yielded more than 1,900 hours of observation, more than ten thousand cases observed, and 690 pages of ethnographic field notes.

The goal of ethnography is not quantification, of course, but instead rich description of actions, people, interactions, scenery, and mood (Paik and Harris 2015). ${ }^{27}$ To focus our attention in these fast-paced and sometimes chaotic environments, and to be able to compare field notes during analysis, we developed a standardized template for writing field notes, shown in online appendix E. Ethnographers were instructed to describe the surroundings and stakeholders in as much detail as possible and were offered prompts to elicit information about such factors as languages heard during court sessions, whether a courtroom was hot or cold, whether cell phones were allowed, or how strictly a bailiff or security guard maintained order. We wrote field notes only for those cases that involved monetary sanctions. A case relevant to monetary sanctions could be as minimal as the judge announcing the statutory fine or fee for a charged offense or as expansive as a full hearing on willful nonpayment. We wrote detailed field notes regarding dialogue, demeanor, emotions, and outcomes for any courtroom event involving LFOs. When completed, field notes were uploaded to the secure project server for coding and analysis.

\section{Year 4: Statewide Administrative Court Data}

Accessing statewide, individual-level, administrative court data in all eight states proved to be the most challenging part of the project. The purpose of the administrative court data was to answer the question of who is sentenced to financial penalties and how much they are charged. The gold standard of administrative court data would be statewide and include defendant characteristics (gender, race, age, nativity, criminal background, and so on), case characteristics (charges, plea, adjudication), court characteristics (judge, lawyers, location), and detailed sentencing information, including financial amounts separated into fines, fees, surcharges, interest, payment penalties, amounts waived, and payment amounts. Ideally the data would be available over multiple (at least five) years, which would allow for examining accruals of interest, surcharges, and collection fees and identifying any subsequent police or court contact (such as warrants issued and incarceration) after sentencing. With robust data, researchers could append population characteristics in a jurisdiction from the census and county-level and city-level sources on factors such as caseload size, fiscal budgets and revenues, and political partisanship.

As illustrated in table 4, we were able to reach this gold standard in only two of the eight study states-Minnesota and Washington. New York State does not collect or maintain state-level data that allow for accurate tracking of monetary sanctions. Data from California, Georgia, Missouri, Illinois, and Texas are incomplete, either because they are not statewide or because they are single-year, not individual-level data, limit the population or type of offense, or do not include LFO amounts. Policy advocacy groups and scholars have written about the lack of access to automated court data in various state systems (see Martin et al. 2018; Rabinowitz, Weisberg, and Pearce 2019).

We made extensive efforts over multiple years to assemble appropriate datasets in all states. That courts are state-level institutions means that no federally collected data exist, and the fragmentation of court systems within states results in uneven recordkeeping and reporting across jurisdictions. Many court systems and jurisdictions operated in a world of paper, carbon copies, file folders, and written orders and entered only minimal information into computers. Details regarding monetary sanctions were often secondary to recording the final dispositions and information about prison time or court-ordered program participation. The extreme localism of court processing and management meant that even when records were digitized they were not necessarily publicly accessible or mergeable. Despite these challenges, we collected an enormous volume of quantitative information. Several articles in this volume use administrative data to investi- 
Table 4. Availability of Administrative Criminal Legal Data by State

\begin{tabular}{ll}
\hline State & Administrative Data Accessed \\
\hline California & Statewide individual-level data on 170,999,663 arrests resulting in 69,269,694 \\
case dispositions from 1990 to 2016 (missing fine/fee amounts) \\
Georgia & Statewide cross-sectional individual-level data on active felony probationers \\
& Statewide aggregate court-level data on monthly LFO collections \\
Illinois & Nearly statewide case-level data on arrests, charges, court dispositions, and \\
& sentences from 2010 to 2018 \\
County-level data for the same information for the most populous county & Statewide individual-level data on arrests, charges, court dispositions, and \\
sinnesota & City-level data from St. Louis Municipal court on 2,168,517 cases resulting in \\
Missouri & $2,072,394$ dispositions in 2017 \\
New York & None \\
Texas & Statewide case-level data on Misdemeanor A, B, and Felony charges from 2010 \\
Washington & to 2016
\end{tabular}

Source: Authors' tabulation.

gate trends and disparities in LFO sentencing and outcomes by race, gender, socioeconomic status, and region in multiple states.

\section{Year 5: Data Management and Processing}

Each state research team managed its own legal review data-spreadsheets with all statutes and documents pertaining to legal challenges to LFOs-courtroom observation spreadsheets, and administrative data. These data were available on the project's central server for analysis at the point of writing a specific paper or report. The surveys, qualitative in-depth interviews, and courtroom ethnographies, on the other hand, required more standardized processing and coding to make them analytically comparable.

We used two methods to manage the survey data. For the court-involved population, researchers followed a link to an online passwordprotected Qualtrics survey where they found a replica of the survey instrument and entered the answers for each unique respondent. We then exported the data from Qualtrics to generate a spreadsheet for all respondents interviewed in the project with rows for each respondent and columns for each survey question. These data were available for analysis in Excel or more advanced statistical data analysis software.

We switched from Qualtrics in Year 2 to entering survey responses directly into Excel in Year 3, for several reasons. First, the Qualtrics interface required an unnecessary middle data-management step given that we ultimately ran data reports in Excel. Second, the Excel file allowed us to include specific tailored instructions for data entry. Third, we learned a great deal about survey execution in Year 2 of the project that we put into practice in Year 3. We learned that we needed more upfront training to ensure that interviewers consistently asked all the questions on the survey, knew how to probe respondents to arrive at maximally precise answers, and knew how to enter ambiguous responses in the spreadsheet. We learned that we could not approach the survey and record the survey information as if it were open-ended; instead, we pushed respondents to be more specific in their answers to the survey questions and we recorded their responses using predetermined variable names and codes. We learned to ensure that all data were entered, saved, and backed up before disposing of the survey sheets. Ultimately, we learned the importance of stan- 
dardization for yielding consistent and comparable data for analysis.

The issue of missing data illustrates the challenges posed in our first foray into survey data collection and management. Among forty-six survey items asked of individuals paying off court debt (see online appendix C), twenty-seven questions are missing data for more than 20 percent of the sample. This figure excludes "don't know" or "refused" answers, which were options for only some of the survey items. Because we did not have codes to specify reasons for missing data for every question, it is unclear whether the data are missing because of a skip pattern, because a given interviewer did not ask the question or enter the response, because the respondent did not know the answer or refused to answer, or because the state team used a not-yet-final survey instrument that omitted certain questions. Although we reconstructed a consistent null response category for when no response was given, in most cases we have no way of distinguishing why data are missing. The extent of missing data is further illustrated in table 5 in the data description section.

The survey data are most complete for misdemeanor and felony convictions, LFO amounts, demographic information, education, employment, and household income. These responses provide a solid foundation for many important analyses. Additionally, once we recognized the shortcomings of the survey design and data-entry process, we compensated by adding a data-entry component to the coding of the interview transcripts. Fortunately, we also audio-recorded the entire survey interaction, which then became a part of the qualitative transcript. This practice provided a second opportunity at the point of coding to register important items covered in the survey or elaborated or clarified in the qualitative responses, even if the researcher was using a different survey instrument. These NVivo Classification Sheets provide another basis for analysis, either as standalone datasets or as data merged with the Qualtrics-Excel output from the surveys.

These hard lessons made the survey data for court actors much cleaner. Of eighty-nine total survey questions asked to the various catego- ries of court actors, only twelve items have missing data for more than 20 percent of the sample. For this round, every state research team used the same survey instrument, we collected more precise survey responses, and we gave clear instructions for entering survey data, including differentiating between missing and nonresponsive answers. For data entry, each state team was given a standardized spreadsheet with instructions. Because the surveys differed across court actors, the spreadsheet included a tab for each court-actor categoryjudges, attorneys (prosecution and defense), probation or community corrections officers, clerks. We developed codebooks for each survey item to transform qualitative answers into numeric values, for example, what type of agency is your probation department? $1=$ Public, $2=$ Private, $3=$ Other (write in). Each state spreadsheet was combined into a master spreadsheet for each court-actor category. These project-wide spreadsheets are the basis for any analyses of the court-actor survey data.

To process the qualitative interview and ethnographic data, we created separate codebooks for interviews with individuals paying LFOs, interviews with decision-makers, and court observation field notes. Codes are themes, actors, actions, or topics that may be of theoretical interest or known to be important from previous empirical research (deductive codes), or may emerge from the research process itself (inductive codes). We developed both kinds. For example, mentions of assessing ability to pay (a deductive code) are important to capture because they relate to Supreme Court rulings, whereas the inductive code case processing emerged as we watched defendants having to return to court several times because their cases were not ready for adjudication. Other codes include topics, emotions, and actors such as reprimand or accountability, indigence, fairness, confusion, stress, discrimination, prejudice or stigma, and collecting agencies.

A codebook is a dictionary that provides detailed definitions for what each code means and examples of the kinds of data that fall into specific codes. For example, the code for warrant in the court-actor codebook is defined as "any conversation about warrants." The definition elaborates that such conversa- 
tions may include asking for warrants, issuing warrants, serving warrants, or mentioning outstanding warrants, and may be related to crimes individuals have committed, warrants related to LFOs, or other topics. ${ }^{28}$ Harris and her research assistants developed first drafts of each codebook. All state PIs and at least one RA from each team added new codes or comments or recommended deletions and revisions. We balanced recognizing team members' wide-ranging research interests (for example, child support, electronic monitoring) with limiting the number of codes to a sum that coders could reasonably keep in play as they coded. This iterative process required several months of discussion, debate, compromise, and resolution for each codebook. The final codebooks for people paying LFOs, court actors, and the ethnographic field notes produced sixty-four, seventy-five, and sixtynine total codes, respectively.

We used NVivo, a qualitative data analysis software, to code our interview transcripts and field notes. Michele Cadigan (research assistant at the University of Washington) created several training videos specific to using NVivo for our project. These videos and accompanying materials were circulated to all state research teams for consistent coding. The NVivo software and all the transcript and field note data were stored on a secure server at the University of Washington, requiring the use of a secure, remote desktop application (Microsoft RDC), to which approved study team members had access. No coding took place outside of the secure-server environment.

Because of missteps in administering the survey and inputting the data from individuals facing LFOs, we recreated some of the survey items in an NVivo Classification Sheet, which is a database function for closed-ended and categorical information. We recorded information for sixteen variables on the Classification Sheet to supplement information that may have been lost in the survey administration or data-entry process. Using the Classification Sheet, we obtained cleaner and more complete data on type of conviction and housing status as well as whether individuals had made payments on their monetary sanctions.

To code the text, we started by calibrating our coding across coders to establish intercoder reliability. This approach informed several small-group and full-team conversations about what codes meant, how much text to code, and how we might use a code's content in future analyses. This process led to revisions of the codebook before beginning to code the full corpus of data. Each state team coded its own interview and ethnographic data over several months. Once all data was coded, researchers could use NVivo to extract all data coded at a specific code, to count text within codes, to conduct searches with a range of Boolean operators, and to search using many other functions. The contributing authors in this volume explain in greater detail the processes they used to analyze the coded qualitative data.

Our final step in data analysis involved writing research papers. The methods section of each article in this volume outlines how the authors used the data to develop and investigate specific research questions. A common theme was the difficulty in striking an objective tone. As scholars of the criminal legal system, stratification, and inequality, we are well aware of racial disparities in institutional processing and the cumulative oppressive effects this system has on poor people and communities of color (Turney and Wakefield 2019). To be fully transparent, we struggled to find purely objective language with which to frame our analyses and inquiries. Engaging with individuals saddled with legal debt during our interviews, hearing the related consequences, and watching those without the means to pay plead for additional time and relief shaped our interpretations and findings. As researchers, our fram-

28. We spent hours discussing the difference between the instructions to code any conversation or to code any substantive conversation. The former is the most thorough and captures any mention of warrants even if in passing or without much consequence, but these data could also be obtained through a simple word search of the database. The directive to code any substantive conversation makes the code output much more useful and relevant but relies heavily on the coder's subjective assessment of an event's substantive value. We had both kinds of instructions and the actual practice likely varied by coder. 
ing of the system of monetary sanctions is informed by the tragedies we witnessed in courtrooms across our eight states. Although we sought to maintain as much objectivity as possible, we were no doubt biased by an interest in humanity and dignity.

\section{Descriptive Data for Individuals \\ Paying Court Debt}

Table 5 presents the demographic characteristics of our sample. The average respondent was approximately thirty-eight years old. In our sample, 41 percent of respondents identified as non-Hispanic white, 33 percent identified as non-Hispanic African American or Black, 15 percent identified as Latinx, and 12 percent chose Other. In our study, approximately 16.5 percent had not earned high school diplomas, nearly 28 percent had earned diplomas, and nearly 56 percent had completed some college education or more. This profile is more educationally advantaged than the incarcerated population-where more than half have not earned a high school diploma (see Ewert, Sykes, and Pettit 2014, table 3) - because our sample is more heterogeneous; many had been convicted of traffic or other low-level, nonjailable offenses.

We also observed a gender imbalance among our respondents that mirrored male overrepresentation in the criminal legal system. About 33 percent of the sample identified as women; men accounted for more than 64 percent. People identifying as transgender made up less than one-tenth of 1 percent. Respondents represented a range of family structures and compositions. Nearly 12.5 percent of the respondents were married, and 9 percent lived with a romantic partner. Almost 25 percent reported being separated, divorced, or widowed; more than half had never been married and were not in a romantic relationship. Nearly half reported having children they were supporting at the time of the interview. Among those with children, approximately 42 percent had one minor child and another 34 percent had two minor children. More than 12.5 percent reported having three children, and 11 percent had four or more minor children.

Employment, earnings, and receipt of public assistance reveal a bleak picture of the finan- cial wellbeing of the respondents and their households. Fewer than half (48.1 percent) of the respondents were employed, and approximately 54 percent earned less than $\$ 1,500$ per month. Only 5 percent reported monthly income in excess of $\$ 5,000$. Household income (which sums the respondent's income with that of other earners in the household) was less than $\$ 1,500$ per month for 51 percent of the sample, but more than $\$ 5,000$ for almost 11 percent. Nearly 65 percent reported receiving some form of public assistance, with an average of 1.25 programs used by respondents receiving aid.

Table 6 displays select measures of the sample population's criminal legal histories and debts. Nearly 95 percent of respondents had been incarcerated at least once in their lives for, on average, 31.2 months. Members of the sample population had been sentenced for 2.7 felonies, disproportionately for nonviolent offenses, with property (34.6 percent) and drug offenses (34.8 percent) the most prevalent categories. Respondents reported convictions for twice as many misdemeanors (6.0), on average, as felonies, with traffic (31 percent) and property ( 25 percent) offenses eclipsing violent offenses (15.9 percent).

Variation in the assessment of LFOs is considerable. About half of the sample faced LFOs below $\$ 3,000$ and 21.8 percent faced LFOs in excess of $\$ 10,000$. The remainder, 28.2 percent, faced LFOs of between $\$ 3,001$ and $\$ 10,000$. Nearly one in seven respondents, 14 percent, reported having payments automatically deducted from their work or other type of payment check. Roughly 70 percent of respondents had made payments on their LFOs, with an average payment of $\$ 3,282$ (the median, not shown, was \$952). In sum, we engaged with a racially and socioeconomically heterogeneous group of respondents with a range of criminal legal experiences. To our knowledge, this research is the largest qualitative study of monetary sanctions.

\section{VOLUME OVERVIEW}

This double issue of RSF: The Russell Sage Foundation Journal of the Social Sciences examines monetary sanctions in the criminal legal system, both how the punishment system itself operates and its ramifications. 
Table 5. Persons with LFOs Sample Demographic Characteristics $(N=519)$

\begin{tabular}{|c|c|c|c|}
\hline Measure & Mean & SD & Observed $\mathrm{N}$ \\
\hline Age & 38.1 & 11.9 & 508 \\
\hline Non-Hispanic White & 0.411 & 0.492 & 492 \\
\hline Non-Hispanic Black & 0.326 & 0.469 & 506 \\
\hline Hispanic & 0.147 & 0.355 & 495 \\
\hline Non-Hispanic Other & 0.119 & 0.324 & 464 \\
\hline U.S. born & 0.963 & 0.189 & 513 \\
\hline Less than high school & 0.165 & 0.372 & 519 \\
\hline High school diploma & 0.277 & 0.448 & 519 \\
\hline Some college or more & 0.558 & 0.497 & 519 \\
\hline Female & 0.337 & 0.473 & 519 \\
\hline Male & 0.642 & 0.480 & 519 \\
\hline Transgender & 0.008 & 0.087 & 519 \\
\hline Married & 0.117 & 0.322 & 519 \\
\hline Live with partner & 0.092 & 0.290 & 519 \\
\hline Separated-divorced & 0.231 & 0.422 & 519 \\
\hline Widowed & 0.015 & 0.123 & 519 \\
\hline Never married & 0.527 & 0.500 & 519 \\
\hline Any children & 0.470 & 0.500 & 511 \\
\hline One minor child & 0.422 & 0.495 & 206 \\
\hline Two minor children & 0.345 & 0.476 & 206 \\
\hline Three minor children & 0.126 & 0.333 & 206 \\
\hline Four or more minor children & 0.107 & 0.310 & 206 \\
\hline Employed & 0.481 & 0.500 & 519 \\
\hline \multicolumn{4}{|l|}{ Monthly Income } \\
\hline$<\$ 500$ & 0.112 & 0.315 & 251 \\
\hline$\$ 501-750$ & 0.092 & 0.289 & 251 \\
\hline$\$ 751-1000$ & 0.120 & 0.325 & 251 \\
\hline$\$ 1,001-1,250$ & 0.112 & 0.315 & 251 \\
\hline$\$ 1,251-1,500$ & 0.104 & 0.305 & 251 \\
\hline$\$ 1,501-2,000$ & 0.127 & 0.334 & 251 \\
\hline$\$ 2,001-2,500$ & 0.108 & 0.310 & 251 \\
\hline$\$ 2,501-3,000$ & 0.064 & 0.245 & 251 \\
\hline$\$ 3,001-5,000$ & 0.112 & 0.315 & 251 \\
\hline$\$ 5,001-7,000$ & 0.024 & 0.153 & 251 \\
\hline More than $\$ 7,000$ & 0.028 & 0.165 & 251 \\
\hline \multicolumn{4}{|l|}{ Monthly household income } \\
\hline$<\$ 500$ & 0.189 & 0.392 & 428 \\
\hline$\$ 501-750$ & 0.077 & 0.267 & 428 \\
\hline$\$ 751-1,000$ & 0.086 & 0.281 & 428 \\
\hline$\$ 1,001-1,250$ & 0.093 & 0.291 & 428 \\
\hline$\$ 1,251-1,500$ & 0.068 & 0.252 & 428 \\
\hline$\$ 1,501-2,000$ & 0.093 & 0.291 & 428 \\
\hline$\$ 2,001-2,500$ & 0.093 & 0.291 & 428 \\
\hline$\$ 2,501-3,000$ & 0.063 & 0.243 & 428 \\
\hline$\$ 3,001-5,000$ & 0.131 & 0.338 & 428 \\
\hline$\$ 5,001-7,000$ & 0.058 & 0.235 & 428 \\
\hline More than $\$ 7,000$ & 0.047 & 0.211 & 428 \\
\hline Any public assistance & 0.648 & 0.478 & 520 \\
\hline Number of public assistance programs & 1.25 & 0.484 & 263 \\
\hline
\end{tabular}

Source: Authors' tabulation. 
Table 6. Persons with LFOs Sample Criminal Justice Characteristics $(N=519)$

\begin{tabular}{|c|c|c|c|}
\hline Measure & Mean & SD & Observed $\mathrm{N}$ \\
\hline Ever incarcerated & 0.948 & 0.221 & 388 \\
\hline Incarceration length (in months) & 31.2 & 50.5 & 338 \\
\hline Number of felonies & 2.68 & 4.47 & 498 \\
\hline Felony property offense & 0.346 & 0.476 & 353 \\
\hline Felony violent offense & 0.201 & 0.401 & 353 \\
\hline Felony drug offense & 0.348 & 0.477 & 353 \\
\hline Felony sex offense & 0.023 & 0.149 & 353 \\
\hline Felony other offense & 0.176 & 0.381 & 353 \\
\hline Number of misdemeanors & 6.0 & 12.2 & 492 \\
\hline Misdemeanor property offense & 0.250 & 0.434 & 364 \\
\hline Misdemeanor violent offense & 0.159 & 0.366 & 364 \\
\hline Misdemeanor drug offense & 0.170 & 0.376 & 364 \\
\hline Misdemeanor sex offense & 0.008 & 0.091 & 364 \\
\hline Misdemeanor traffic offense & 0.310 & 0.463 & 364 \\
\hline Misdemeanor other offense & 0.107 & 0.310 & 364 \\
\hline \multicolumn{4}{|l|}{ LFO amount assessed } \\
\hline 0 & 0.006 & 0.077 & 499 \\
\hline$<\$ 500$ & 0.140 & 0.348 & 499 \\
\hline$\$ 501-1,000$ & 0.102 & 0.303 & 499 \\
\hline$\$ 1,001-2,000$ & 0.154 & 0.361 & 499 \\
\hline$\$ 2,001-3,000$ & 0.104 & 0.305 & 499 \\
\hline$\$ 3,001-4,000$ & 0.064 & 0.245 & 499 \\
\hline$\$ 4,001-5,000$ & 0.050 & 0.218 & 499 \\
\hline$\$ 5,001-6,000$ & 0.050 & 0.222 & 499 \\
\hline$\$ 6,001-7,000$ & 0.026 & 0.159 & 499 \\
\hline$\$ 7,001-8,000$ & 0.024 & 0.153 & 499 \\
\hline$\$ 8,001-9,000$ & 0.032 & 0.176 & 499 \\
\hline$\$ 9,001-10,000$ & 0.026 & 0.159 & 499 \\
\hline More than $\$ 10,000$ & 0.218 & 0.413 & 499 \\
\hline Payments deducted from work-payment check & 0.135 & 0.342 & 497 \\
\hline Made payments on LFOs & 0.718 & 0.450 & 504 \\
\hline Total paid on LFOs & $\$ 3,282$ & $\$ 8,895$ & 328 \\
\hline
\end{tabular}

Source: Authors' tabulation.

The System of Monetary Sanctions

The first issue includes research on how the system of monetary sanctions is architecturally designed by policymakers through the enactment of law and how court actors interpret and apply the law. Section 1 presents policy-related papers that examine similarities and differences in state enactment of legislative codes and statutes that apply monetary sanctions, highlighting laws on the books. Section 2 presents analyses of law on the ground, or how actors interpret and apply laws in the various in- stitutions that make up the criminal legal world. The section concludes with an article that outlines directions for policy, practice, and research on the causes and consequences of financial penalties in the criminal legal system.

In the first article, "Beyond the Penal Code," Anjuli Verma and Bryan Sykes examine how the architecture of law-or the distribution of monetary sanctions across legislative codes sections-should inform analyses of LFOs. The authors conduct a legal census of the entire California Legislative Code and find that one 
in twenty-three statutes contains rules pertaining to monetary sanctions and that these statutes are dispersed throughout every section of the legislative code. Their findings demonstrate the tentacle-like nature of monetary sanctions and highlight the importance of breaking civil-criminal boundaries in research on monetary sanctions to reveal impacts well beyond the penal system.

In "Sensemaking in the Legal System," Tyler Smith, Kristina Thompson, and Michele Cadigan study how court actors interpreted and applied new monetary sanctions laws. They find that the process by which court actors communicate, interpret, and negotiate legal changes is shaped by a variety of contextual factors. Specifically, they find that a strong regulatory agency helped create conformity, but that local normative and cultural factors still shaped legal interpretation and implementation across jurisdictions within each state. Their work has important implications for policymakers because it highlights the many factors that produce legal and organizational variation between courtrooms.

In "The 'Damaged' State vs. the 'Willful' Nonpayer," April Fernandes, Brittany Friedman, and Gabriela Kirk analyze a little-known state practice of suing incarcerated people for the cost of their room and board. Using a review of 102 such lawsuits in Illinois, the authors apply legal frames and the concept of rentseeking to investigate how the state justifies seeking financial damages and minimizes the harm caused by pay-to-stay lawsuits. Their analysis reveals a legal system that shifts the cost and moral burden to incarcerated people through the application of the willful nonpayer label. The research identifies a neoliberal shift away from welfare provisions toward an almost predatory legal mechanism whereby the state can punish the people in prison in perpetuity through creating a group the authors term perpetual debtors.

In the second section of the first issue, we examine how the process of monetary sanctions operates on the ground within the courts and other spaces we studied. The article by Beth Huebner and Andrea Giuffre, "Reinforcing the Web of Municipal Courts," takes us to Ferguson, Missouri. Perhaps more than any other
U.S. locality, Ferguson was shaken by events that shed light on the relationship between aggressive policing, municipal revenue generation, and predatory and unrelenting monetary entanglements with the courts. Huebner and Giuffre investigate court practices in Ferguson and St. Louis County after reforms. The authors document what is known locally as the munishuffle, whereby individuals are cited for violations in several towns and struggle to manage scattered court appearances and mounting financial debt. In the St. Louis region, parochialism, fragmentation, and autonomy ensure that a disproportionate burden on African American and poor defendants has persisted well after reforms were instituted.

In "Pay or Display," Karin Martin and her coauthors uncover striking similarities in New York and Illinois courts in requiring significant time from defendants in lieu of full payment. Because most low-income defendants are unable to pay their monetary sanctions immediately, they are subjected to repeated and prolonged post-sentencing payment-status hearings. In both states, and in contrast to most other sites in the study, the emphasis is more on the time needed for payment rather than on willful nonpayment. The authors propose that in prioritizing procedural integrity, or fidelity to local norms of case processing, the practices of the courtroom workgroups rarely prompt full payment. Instead, defendants are routinely called upon to demonstrate their accountability by going to court repeatedly over often extended periods. Although this performance of compliance together with any signs of deference and contrition displayed in court can engender leniency, actual outcomes tend to result in excessive demands on time rather than substantive justice.

Individuals with few financial resources spend a long time trying to pay off court debt. This means they are often involved in other state systems that serve, process, support, and surveil poor people, especially the various agencies of the welfare state. In "Robbing Peter to Pay Paul," Bryan Sykes and his coauthors use nationally representative data and survey data from seven of the eight study states to show how two faces of the state work in contrasting ways: some government agencies issue mone- 
tary benefits that require clients to share information about their families, finances, and whereabouts, whereas other state entities-like courts-issue monetary penalties that engender avoidance and reticence. They find that roughly half of criminal defendants facing. LFOs are also receiving some kind of meanstested state benefit, such as food stamps, Medicaid, and disability payments. Defendants thus become conduits through which state welfare aid is redirected to the punitive criminal legal system.

The monetary and nonmonetary costs of probation in Georgia and Missouri is the focus of the article by Beth Huebner and Sarah Shannon. To comply with probation terms, most individuals must pay court fines and fees, but probation itself can generate additional costs. The proliferation of private probation companies in both Georgia and Missouri creates opportunities for excessive profiteering with little oversight by public agencies. By analyzing interviews with individuals on probation in the two states and observing courtroom probation appearances, Huebner and Shannon demonstrate how probation terms under private supervision become disproportionately punitive-both relative to wealthier defendants and given the crime committed-for individuals who struggle to pay off their monetary sanctions.

Focusing on how place and density influence courtroom dynamics, Gabriela Kirk and her coauthors explore law on the ground across different geographies. Courtroom ethnographies and interviews with court actors in Illinois, Georgia, Minnesota, and Missouri reveal that localities with smaller populationsmostly rural and smaller suburban areas-featured dense relationship networks among court actors and between court actors and defendants. Such familiarity in courtroom settings makes court authorities more sympathetic and moralistic toward defendants, resulting variously in financial accommodations or inflexibility. The authors find far less familiarity in major cities, where the imposition of LFOs was much more routinized and perfunctory. Geographic differences in stakeholders' stances toward LFOs were notable. This article highlights the extreme localism of the application of law and policy and suggests how reforms should also consider such specificities.

In the final paper of this first issue, "What Is Wrong with Monetary Sanctions?, Brittany Friedman and her colleagues summarize how monetary sanctions thwart notions of justice. They outline the unequal exposure to the criminal legal system certain populations and communities face, discuss the uneven assessments of monetary sanctions, and examine the disparate impacts of penal debt. The authors outline the lived experiences of people sentenced to monetary sanctions such as expanded system involvement and the arbitrary and excessive nature of fiscal penalties. The authors provide a number of key policy recommendations to improve the administration of justice, mitigate some of the most harmful effects of monetary sanctions, and advance future research.

\section{The Consequences of Monetary Sanctions}

The second issue of the volume examines the ramifications of the system of monetary sanctions. The first section examines the lived experiences of interviewees and others observed in courtrooms across the eight states. These articles examine characteristics of individuals sentenced to monetary sanctions and demonstrate the consequences of debt for families and localities. The second section focuses on the disparate impacts that have been observed in the course of our research. These papers highlight how structural inequalities in the application of monetary sanctions intersect and reverberate across other dimensions of social inequality.

Existing research shows that conviction and incarceration increase individual risks of chronic and acute health conditions, but no research has been done on the emotional health effects of monetary sanctions. Alexes Harris and Tyler Smith fill this gap. Drawing on Leonard Pearlin's (1989) stress process paradigm, they suggest that monetary sanctions create not only legal and economic precarity for people who owe penal debt, but also an overwhelmingly palpable sense of fear, frustration, anxiety, and despair. The authors theorize the ways in which monetary sanctions serve as both acute and chronic health stressors for people 
who are unable to pay off their debts, highlight the mechanisms linking penal debt with mental and emotional burdens, and generalize their findings using national data from the United States Federal Reserve. They find that the system of monetary sanctions, through the eyes of people carrying the debt, generates a great deal of stress and strain that becomes an internalized punishment affecting many realms of people's lives.

Housing instability is a major social problem exacerbated by growing socioeconomic inequality. Mary Pattillo and her coauthors extend sociological and sociolegal inquiries into housing instability by examining how financial penalties operate independently of incarceration and the mark of a criminal record to affect housing. They show how a "housing instability-LFO nexus" emerges out of the monetary sanctioning system that induces further financial hardships while deepening strain and undermining housing stability. By leveraging quantitative and qualitative data from national and state-level sources, their work demonstrates how monetary sanctions require situating housing instability within the vicious cycle of structural and individual factors that impinge on, and cascade across, social, economic, and familial contexts.

Next, Amairini Sanchez and her colleagues shift our focus to immigration, in particular crimmigration - the intersection of criminal and immigration law and practice. Yet, scholarship on crimmigration overlooks one important mechanism in the crime and immigration nexus: the system of monetary sanctions. In this article, Sanchez and her colleagues examine how immigration status shapes the imposition of monetary sanctions. They find that immigrants are financially exploited through gaps in criminal and immigration law that allow for bail predation. For example, the liminal legal status of undocumented immigrants squeezes them in a trade-off between higher financial penalties and less or no jail time, reducing the risk of deportation while burdening them financially. These individuals thus face crimmigration sanctions that arise from opaque spaces in the law that allow judges and prosecutors to impose higher fines and fees, in some cases enabling these individuals to avoid detection by immigration officials. Crimmigration sanctions fuel social inequality within the immigrant community and between immigrants and other defendants, thereby depriving immigrants of due process rights.

The final article in section 1 of the second issue looks at lived experiences not for people assessed legal debt but for their families. In "Monetary Sanctions and Symbiotic Harms," Daniel Boches and his colleagues argue that the notion of symbiotic harms - the negative effects of punishment on family-is also relevant to understanding the impact of monetary sanctions. Legally innocent family members are often leveraged by probation officers to pay the debt of their legal system-involved relatives, and monetary sanctions increase the economic strain, emotional distress, and interpersonal conflict families experience. Social bonds facilitate the repayment of criminal legal debt despite inducing other forms of hardship and severe deprivation. The authors demonstrate how these symbiotic harms place kinship networks at risk of permanent damage from a system that prioritizes the repayment of criminal legal debt.

Section 2 of the second issue examines the disparate effects of monetary sanctions for those who shoulder the burden of penal debt. In "Incomparable Punishments," Lindsay Bing, Becky Pettit, and Ilya Slavinski show how sentencing that imposes standardized legal fines and fees lands unequally on defendants by race. The authors analyze administrative court data and in-depth interviews with respondents in Texas, finding that Black residents carry a disproportionate debt burden and, as a result, are exposed to differential criminal legal treatment and consequences relative to White Texans. This article demonstrates clearly how seemingly race-neutral policies can result in racially disparate outcomes in practice.

Similarly, Robert Stewart and his colleagues explore the disparate application of monetary sanctions in sentences imposed on Native Americans in Minnesota. The authors use a multimethod research design and present descriptive statistics in comparing fiscal sentences given to Native Americans and other groups. They find geographic disparities in LFO sentences and debt; counties located in proxim- 
ity to Native American reservations show the highest mean LFO debt relative to other counties. They also find that, compared with other groups, Native Americans are second to Latinos and Latinas in fiscal penalties assessed at sentencing but carry a significantly larger debt burden than any other group. Qualitative interviews reveal how driver's license suspension because of LFO nonpayment in rural reservation communities limited respondents' ability to work, given the few transportation options available. The authors offer a powerful theoretical framework that illustrates how settler colonial domination has shifted from collective to individual wealth extraction.

The final article in this issue and the volume, by Kate O'Neill, Tyler Smith, and Ian Kennedy, studies gender and locational differences in the imposition of monetary sanctions. In an analysis of automated court data from the Washington State Administrative Office of the Courts, the authors find a positive association between county dependence on monetary sanctions and rates at which women are sentenced to incarceration. They find no differences, however, in reliance on revenues between rural and nonrural counties. The analysis implies that the system of monetary sanctions is linked to women's incarceration rates and that this association is likely driven by women's poverty and the policing of low-level offenses rather than by a county's fiscal needs. The article reveals how monetary sanctions matter for population subgroups beyond race-ethnicity, and identifies other factors that contribute to shaping the monetary sanctions system.

\section{CONTRIBUTIONS OF THIS VOLUME}

Based on the studies presented in this volume and our ongoing collective research, we make three primary arguments about the variation in and reach of monetary sanctions. First, laws and policies vary not only across states, but within them as well, and monetary sentencing practices diverge even within the same courthouse. The articles presented here show clearly that the system of monetary sanctions is fragmented, sprawling, disjointed, and often opaque, without much oversight or regulation despite being rooted in law and regulation (Verma and Sykes 2022; Fernandes, Friedman, and Kirk 2022, this volume). The power to set monetary sanctions lies at the federal, state, and local levels, but who actually governs LFOs in practice can move between judge, clerk, probation officer, prosecutor, collections agent, or even an online payment interface. Discretion, discrimination, carelessness, confusion, and idiosyncrasies can creep in at any one of those levels, making a highly consequential sentence subject to considerable unpredictability. Even though LFOs are routinely and widely imposed for traffic, misdemeanor, and felony cases, many people in the court system did not know how much they owed. None of the states we studied had a central state repository where information on the total amount owed could be found. Even the nomenclature for LFOs-fees, surcharges, costs, assessments, and so on - varied across states.

This primary finding of intense variation helps explain how and why individuals who are processed in this system feel disempowered and perpetually punished and in debt, as the articles in this volume illustrate. Variation also sheds light on the fiscal and legal inefficiencies at the institutional level, such as the slippage between policy reform and policy enactment within courtrooms (Smith, Thompson, and Cadigan 2022, this volume), or the redirection of public dollars from welfare state expenditures to criminal legal revenues (Sykes et al. 2022, this volume). Ultimately, such lack of uniformity and standardization highlights the challenges of instituting meaningful and effective change. Our findings show that operating within the current system allows for only piecemeal efforts-a law change in one city or a legal ruling in one state. On other hand, sweeping transformation of the system would require action at the Supreme Court or federal level, or a substantial chain reaction of state actions. Brittany Friedman and her colleagues (2022, this volume) take up this issue further.

Second, our work demonstrates the importance of examining the system of monetary sanctions in its entirety. Figure 1 illustrates the tentacles of this system and how penal debt and related precarious financial statuses, coupled with legal and social control, negatively affect one's relationships with a variety of institutions, people, and situations. Our scholar- 
Figure 1. The Extensive Reach of Monetary Sanctions' Tentacles in the Sociological World



Source: Authors' framing.

ship reveals how monetary sanctions can disrupt reintegrative practices for the formerly incarcerated through disruptions to employment, housing, mobility (transportation), and health. The financial burdens and the related legal consequences may disrupt family formation and stability, limiting parents' capacity to be healthy and present in their children's lives. Hence, research on families and children should investigate the potential intergenerational effects of both poverty and the oppressively constant criminal legal control that penal debt triggers. Although not explored in the articles in this volume, monetary sanctions' tentacles may also reach into the realms of education, credit profiles, voting rights (Uggen et al. 2020), community organization and stability (O’Neill, Kennedy, and Harris forthcoming), and wealth accumulation (Maroto and Sykes 2020; Sykes and Maroto 2016).

Our conceptualization of the tentacles of monetary sanctions must be situated within an understanding of the hegemony of neoliberal ideologies generally and in the criminal legal system in particular. We see how shifts in governmental policies that center notions of personal accountability and merit become mechanisms for controlling and subjugating populations (Martin, Spencer-Suarez, and Kirk 2022 , this volume). The criminal legal system has evolved into a service-based institution that charges costs and fees per person processed. Individuals are now expected to pay for the "services" rendered by police, judges, attorneys, juries, and clerks. For many, these costs are immediately transformed into penal debt, 
potentially exposing them to a variety of garnishment mechanisms (Heubner and Shannon 2022) and the redistribution of means-tested public support (Sykes et al. 2022, this volume). From a neoliberal perspective, this debt becomes a social provision (A. Atkinson 2017, 2019), replacing what was formerly a public service supported by taxpayer monies. It is this market-based relationship that puts people in debt to the court and to the state and occasions the multiple collateral impacts that the articles in this volume elucidate. What is proffered as a less restrictive or less harmful intermediate punishment in reality carries a wealth of longterm negative consequences.

Finally, the system of monetary sanctions structures racial and class subjugation and social control. It is plain that poor people are most affected by monetary sanctions. The inability to pay is what triggers repeated court appearances, probation violations, prolonged system involvement, and even incarceration. Affluent people, on the other hand, pay and move on. As a money-based punishment, the class inequalities that monetary sanctions create are perhaps self-evident. Nonetheless, the articles in this volume offer definitive empirical evidence in support of this claim. We also study seriously the racial contours of monetary sanctions. Several articles in this volume show that Black, Latinx, and Native Americans are disproportionately processed within the criminal legal system and, as a result, carry a disproportionate burden of criminal legal debt (Sanchez et al. 2022; Bing et al. 2022; Stewart et al. 2022; O'Neill et al. 2022).

We argue that the contemporary system of monetary sanctions embodies the same hallmarks and historical vestiges of past peculiar institutions (Wacquant 2001). The indebtedness that LFOs beget constitutes an extensive mechanism of social control, requiring unending amounts of people's time and money, and imposing the constant threat of their bodies' being taken into custody. However, the system of monetary sanctions now operates within a putatively colorblind era. According to Eduardo Bonilla-Silva, "contemporary racial inequality is reproduced through 'new racism' practices that are subtle, institutional, and apparently nonracial" $(2018,3)$. Supposed race-neutral po- litical ideologies operate "without naming those who it subjects and those who it rewards" (3-4). Although policymakers and practitioners view policies governing monetary sanctions as largely race neutral, we uncover racialized disparities in outcomes. Moreover, even the research in this volume that does not investigate racial disparities head-on is informed by the fact that Black, Latinx, and Native American people are disproportionately surveilled, detained, and punished in the U.S. criminal legal system, including immigration law. Therefore, every finding presented here-from the negative emotional health effects of monetary sanctions to the predation of private probation agencies to the impacts on innocent family members-should be read as falling most heavily on Black and Brown people.

\section{FUTURE RESEARCH}

After five years of data collection, coding, and analysis, we have learned much about the system of monetary sanctions in the states under study, yet the questions and observations presented in our research raise new questions and open deeper lines of inquiry as we plot the future direction of this work. As examples, we did not endeavor to compare the system of monetary sanctions in sentencing with other sentencing modes. We have yet to conduct statistical analyses that measure recidivism rates for those with legal debt and those without. Our interview data illustrate that the difficulties of carrying penal debt spill over into the ability to secure housing, maintain employment, and remain healthy. We have not, however, illustrated these relationships statistically.

Moreover, we did not conduct a cost-benefit analysis of court costs imposed and the expenditures necessary to monitor and collect outstanding debt. Although nonacademic reports suggest that in some jurisdictions courts spend more to collect debts than the value of the debts themselves, recouping only pennies on the dollar (Financial Justice Project 2018), important questions remain about how much money is outstanding and collected by local and state jurisdictions, and how the monies are allocated and to whom. For example, to what extent do the jurisdictions we examine rely on fines and fees to generate revenue? And how much are 
these jurisdictions paying to recoup outstanding fines and fees?

Finally, because our scope of work focused on traffic, misdemeanor, and criminal courts, we did not explore monetary sanctions for people with civil, juvenile, or federal sentences; nor did we examine the practice and consequences of civil asset forfeiture. These topics merit sociolegal and policy analysis.

\section{CONCLUSION}

Our collective project exemplified a unique academic endeavor. The multistate, multimethod study of monetary sanctions generated a wealth of data and ideas while constructing a collaborative learning and training environment for students and faculty. At the outset, Harris sought to shape a "dream team" of scholars with the aim of collecting data to produce methodologically sound and conceptually informed research that could inform the construction of empirical and theoretical frameworks for research on monetary sanctions. She also sought to build a team of established scholars while training and developing a generation of young scholars in multimethod approaches that include on-the-ground and field experience, spurring new research questions, theories, and empirical inquiries into the system of monetary sanctions. ${ }^{29}$

Our project demonstrates how scholars sharing insights and conceptual frames can develop research agendas that collectively engage all team members in primary data collection and analysis to provide a broad and detailed understanding of an important social system and the accompanying dynamics. To this end, we communicated extensively throughout our project. We developed protocols for authorship, time management, and manuscript development. This is not to say that disagreements, negotiations, and other bumps in the road did not require delicate attention. Nonetheless, we were able to model supportive collaborations in which we addressed and incorporated a diversity of opinions and concerns along the way. Our project also illustrates how we engaged on- the-ground training for undergraduate and graduate students, postdocs, and junior faculty. Every member of our team was able to contribute to instrument design as well as data collection, management, and analysis. Collaborators were encouraged to develop papers across states and areas of interest. The papers and findings produced by the Multi-State Study of Monetary Sanctions truly reflect a collaborative endeavor, shaped by many hands and protean minds.

To conclude, the system of monetary sanctions creates, perpetuates, and exacerbates inequality via one purposeful system of punishment. Our research shows how monetary sanctions and the related debt that poor individuals shoulder creates, perpetuates, and worsens impoverished lives. Despite these chilling findings, the system dynamics associated with monetary sanctions suggest very clear policy reforms that could disrupt negative outcomes. In this volume, Brittany Friedman and colleagues detail policy implications related to our project's findings. In general, we suggest both incremental and dramatic reforms. In no way has this study answered all the relevant and important sociological and legal questions related to monetary sanctions; our work, however, should be instructive to scholars regarding the several directions future studies could take. Most important, our work highlights how one set of policy practices can undermine many societal domains and institutions that facilitate the ability to lead successful, healthy, and happy lives. In so doing, this volume offers a cornucopia of research threads and policy avenues that we hope will disrupt, or dramatically attenuate, the effects of the monetary sanctioning system throughout the United States.

\section{REFERENCES}

Aguiar, Luis L. M., and Christopher J. Schneider. 2016. Researching Amongst Elites: Challenges and Opportunities in Studying Up. New York: Routledge. American Civil Liberties Union (ACLU). 2010. In for a Penny: The Rise of America's New Debtors Prison. Washington, DC: American Civil Liberties

29. We would be remiss if we did not mention that our team purposefully centered health, wellness, and family within our state teams and across the full team. We had regular discussions about the importance of balancing family, health, and work, and at each in-person meeting celebrated our personal life accomplishments. 
Union. Accessed July 23, 2021. https://www .aclu.org/report/penny-rise-americas-new -debtors-prisons.

ArchCity Defenders. 2014. “ArchCity Defenders: Municipal Courts White Paper." St. Louis, Mo.: ArchCity Defenders. Accessed July 23, 2021. https:// www.archcitydefenders.org/wp-content/uploads /2019/03/ArchCity-Defenders-Municipal-Courts -Whitepaper.pdf.

Atkinson, Abbye. 2017. “Consumer Bankruptcy, Nondischargeability, and Penal Debt." Vanderbilt Law Review 70(3): 917-83.

- 2019. "Rethinking Credit as Social Provision." Stanford Law Review 71(5): 1093-162.

Atkinson, Torie. 2016. "A Fine Scheme: How Municipal Fines Become Crushing Debt in the Shadow of the New Debtors' Prisons." Harvard Civil Rights-Civil Liberties Law Review 51(1): 189-238.

Bannon, Alicia, Mitali Nagrecha, and Rebekah Diller. 2010. “Criminal Justice Debt: A Barrier to ReEntry." New York: Brennan Center for Justice. Accessed July 23, 2021. https://www.brennancenter .org/sites/default/files/2019-08/Report_

Criminal-Justice-Debt-\%20A-Barrier-Reentry.pdf.

Beckett, Katherine, Alexes Harris, and Heather Evans. 2008. "The Assessment and Consequences of Legal Financial Obligations in Washington State." Olympia: Washington State Minority and Justice Commission. Accessed July 23, 2021. https://media.spokesman.com/documents/2009 /05/study_LFOimpact.pdf.

Bender, Alex, Stephan Bingham, Mari Castaldi, Elisa Della Piana, Meredith Desautels, Michael Herald, Endria Richardson, Jesse Stout, and Theresa Zhen. 2015. "Not Just a Ferguson Problem: How Traffic Courts Drive Inequality in California." San Francisco: Lawyers' Committee for Civil Rights of the San Francisco Bay Area. Accessed July 23, 2021. https://lccrsf.org/wp-content/uploads/Not -Just-a-Ferguson-Problem-How-Traffic-Courts -Drive-Inequality-in-California-4.8.15.pdf.

Berkeley Law. 2019. "Fee Abolition and the Promise of Debt-Free Justice for Young People and Their Families in California." Berkeley: University of California, Policy Advocacy Clinic. Accessed July 23, 2021. https://www.law.berkeley.edu/wp -content/uploads/2019/10/SB-190 -Implementation-Report11_10_31_19.pdf.

Bing, Lindsay, Becky Pettit, and Ilya Slavinski. 2022. “Incomparable Punishments: How Economic Inequality Contributes to the Disparate Impact of
Legal Fines and Fees." RSF: The Russell Sage Foundation Journal of the Social Sciences 8(2): 118-36. DOI: https://doi.org/10.7758/RSF.2022 8.2.06.

Bonilla-Silva, Eduardo. 2018. Racism Without Racists: Color-Blind Racism and the Persistence of Racial Inequality in America. Lanham, Md.: Rowman \& Littlefield.

Boches, Daniel, Brittany T. Martin, Amairini Sanchez, Aubrianne L. Sutherland, Andrea Giuffre, and Sarah K.S. Shannon. 2022. "Monetary Sanctions and Symbiotic Harms." RSF: The Russell Sage Foundation Journal of the Social Sciences 8(2): 98-115. DOI: https://doi.org/10.7758/RSF .2022.8.2.05.

Brett, Sharon. 2020. "Reforming Monetary Sanctions, Reducing Police Violence." UCLA Criminal Justice Law Review 4(1): 17-48.

Cadigan, Michele, and Gabriella Kirk. 2020. “On Thin Ice: Bureaucratic Processes of Monetary Sanctions and Job Insecurity." RSF: Russell Sage Foundation Journal of the Social Sciences 5(1): 113-31. DOI: https://doi.org/10.7758/RSF.2020 6.1.05.

Colgan, Beth A. 2017. “Graduating Economic Sanctions According to Ability to Pay." lowa Law Review 103(1): 53-112.

_ 2018. "The Excessive Fines Clause: Challenging the Modern Debtors' Prison." UCLA Law Review 65(2): 2-77.

_. 2019. "Wealth-Based Penal Disenfranchisement." Vanderbilt Law Review 72(1): 55-189.

Criminal Justice Policy Program. 2016. “Confronting Criminal Justice Debt: A Guide for Policy Reform." Cambridge, Mass.: Harvard Law School. Accessed July 23, 2021. https://cjdebtreform.org /sites/criminaldebt/themes/debtor/blob /Confronting-Crim-Justice-Debt-Guide-to-Policy -Reform.pdf.

Crowley, Michael. F, Matthew J. Menendez, and Lauren-Brooke Eisen. 2020. "If We Only Knew the Cost: Scratching the Surface on How Much It Costs to Assess and Collect Court Imposed Criminal Fees and Fines." UCLA Criminal Justice Law Review 4(1): 165-76.

deVuono-Powell, Saneta, Chris Schweidler, Alicia Walters, and Azadeh Zohrabi. 2015. “Who Pays? The True Cost of Incarceration on Families." Oakland, Calif.: Ella Baker Center, Forward Together, Research Action Design. Accessed July 23, 2021. http://whopaysreport.org/who-pays-full-report. 
Edwards, Frank. 2020. “Fiscal Pressures, the Great Recession, and Monetary Sanctions in Washington Courts of Limited Jurisdiction." UCLA Criminal Justice Law Review 4(1): 157-64.

Edwards, Frank and Alexes Harris. 2020. “An Analysis of Court Imposed Monetary Sanctions in Seattle Municipal Courts, 2000-2017." Seattle, Wash.: Office for Civil Rights. Accessed July 23, 2021. https://www.seattle.gov/Documents /Departments/CivilRights/SMC\%20Monetary \%20Sanctions\%20Report\%207.28.2020 $\% 20 F I N A L$.pdf.

Ewert, Stephanie, Bryan Sykes, and Becky Pettit. 2014. "The Degree of Disadvantage: Incarceration and Inequality in Education." Annals of the American Academy of Political and Social Science 651(1): 24-43.

Fergus, Devin. 2018. Land of the Fee: Hidden Costs and the Decline of the American Middle Class. New York: Oxford University Press.

Fernandes, April D., Michelle Cadigan, Frank Edwards, and Alexes Harris. 2019. "Monetary Sanctions: A Review of Revenue Generation, Legal Challenges, and Reform." Annual Review of Law and Social Science 15(1): 397-413.

Fernandes, April D., Brittany Friedman, and Gabriela Kirk. 2022. “The 'Damaged' State vs. the 'Willful' Nonpayer: Pay-to-Stay and the Social Construction of Damage, Harm, and Moral Responsibility in a Rent-Seeking Society." RSF: The Russell Sage Foundation Journal of the Social Sciences 8(1): 82-105. DOI: https://doi.org/10 .7758/RSF.2022.8.1.04

Financial Justice Project. 2018. “Criminal Justice Administrative Fees: High Pain for People, Low Gain for Government." San Francisco: Office of the Treasurer \& Tax Collector and the County of San Francisco. Accessed July 23, 2021. https:// sftreasurer.org/high-pain-low-gain.

Fines and Fees Justice Center. 2020. “Budget Alternatives." Accessed July 23, 2021. https://fines andfeesjusticecenter.org/covid-19-policy -tracker/budget-alternatives.

Friedman, Brittney, and Mary Pattillo. 2019. “Statutory Inequality: The Logics of Monetary Sanctions in State Law." RSF: Russell Sage Foundation Journal of the Social Sciences 5(1): 174-96. DOI: https://doi.org/10.7758/RSF.2019.5.1.08.

Friedman, Brittany, Alexes Harris, Beth M. Huebner, Karin D. Martin, Becky Pettit, Sarah K.S. Shannon, and Bryan L. Sykes. 2022. “What Is Wrong with Monetary Sanctions? Directions for Policy, Practice, and Research." RSF: The Russell Sage Foundation Journal of the Social Sciences 8(1): 221-43. DOI: https://doi.org/10.7758/RSF .2022.8.1.10.

Garrett, Brandon L., Karima Modjadidi, and William Crozier. 2020. “Undeliverable: Suspended Driver's Licenses and the Problem of Notice." UCLA Criminal Justice Law Review 4(1): 185-98.

Goldstein, Rebecca, Michael W. Sances, and Hye Young You. 2020. “Exploitative Revenues, Law Enforcement, and the Quality of Government Service." Urban Affairs Review 56(1): 5-31.

Gordon, Margaret A., and Daniel Glaser. 1991. "The Use and Effects of Financial Penalties in Municipal Courts." Criminology 29(4): 651-76.

Greenberg, Claire, Marc Meredith, and Michael Morse. 2016. “The Growing and Broad Nature of Legal Financial Obligations: Evidence from Court Records in Alabama." Connecticut Law Review 48(4): 1079-120.

Hammons, Brianna. 2021. "Tip of the Iceberg: How Much Criminal Justice Debt Does the U.S. Really Have?" New York: Fines and Fees Justice Center. Accessed July 23, 2021. https://finesandfees justicecenter.org/content/uploads/2021/04/Tip -of-the-Iceberg_Criminal_Justice_Debt_BH1.pdf.

Harris, Alexes. 2016. A Pound of Flesh: Monetary Sanctions as Punishment for the Poor. New York: Russell Sage Foundation.

Harris, Alexes. 2020. “Framing the System of Monetary Sanctions as Predatory: Policies, Practices, and Motivations." UCLA Criminal Justice Law Review 4(1): 1-8.

Harris, Alexes, Heather Evans, and Katherine Beckett. 2010. “Drawing Blood from Stones: Legal Debt and Social Inequality in the Contemporary United States." American Journal of Sociology 115(6): 1755-99.

. 2011. "Courtesy Stigma and Monetary Sanctions: Toward a Socio-Cultural Theory of Punishment." American Sociological Review 76(2): 1-31.

Harris, Alexes, Beth M. Huebner, Karin D. Martin, Mary Pattillo, Becky Pettit, Sarah K.S. Shannon, Bryan L. Sykes, and Christopher Uggen. 2018. “United States Systems of Justice, Poverty and the Consequences of Non-Payment of Monetary Sanctions: Interviews from California, Georgia, IIlinois, Minnesota, Missouri, Texas, New York, and Washington." Multi-State Study Report no. 2. 
Houston, Tex.: Laura and John Arnold Foundation. Accessed July 23, 2021. http://www .monetarysanctions.org/wp-content/uploads /2018/01/Monetary-Sanctions-2nd-Year-Report .pdf.

Harris, Alexes, Tyler Smith, and Emmi Obara. 2019.

"Justice 'Cost Points': Examination of Privatization within Public Systems of Justice." Crime and Public Policy 18(2): 343-59.

Henrichson, Christian, Stephen Roberts, Chris Mai, Ayesha Delany-Brumsey, Mathilde Laisne, Chelsea Davis, and Rose Wilson. 2017. “The Costs and Consequences of Bail, Fines and Fees in New Orleans." New York: Vera Institute of Justice. Accessed July 23, 2021, https://www.vera .org/downloads/publications/past-due-costs -consequences-charging-for-justice-new-orleans -technical-report.pdf.

Henricks, Kasey, and Daina Cheyenne Harvey. 2017. "Not One but Many: Monetary Punishment and the Fergusons of America." Sociological Forum 32(S1): 930-51.

Herrera, Lucero, Tia Koonse, Melanie SonstengPerson, and Noah Zatz. 2019. “Work, Pay, or Go to Jail: Court-Ordered Community Service in Los Angeles." In Money and Punishment Circa, 2020, edited by Anna VanCleave, Brian Highsmith, Judith Resnik, Jeff Selbin, and Lisa Foster, 105-08. New Haven, Conn., and Berkeley, Calif.: Arthur Liman Center for Public Interest Law at Yale Law School and Policy Advocacy Clinic at UC Berkeley School Law. Accessed July 23, 2021. https:// digitalcommons.law.yale.edu/cgi/viewcontent.cgi ?article $=1027 \&$ context $=$ amlaw.

Huebner, Beth , and Sarah K.S. Shannon. 2022. “Private Probation Costs, Compliance, and the Proportionality of Punishment: Evidence from Georgia and Missouri." RSF: The Russell Sage Foundation Journal of the Social Sciences 8(1): 179-99. DOI: https://doi.org/10.7758/RSF.2022 8.1.08.

Highsmith, Brian, ed. 2020. "Fees, Fines, and the Funding of Public Services: A Curriculum for Reform." New Haven, Conn., Cambridge, Mass., Berkeley, Calif.: Arthur Liman Center for Public Interest Law at Yale Law School, Criminal Justice Policy Program at Harvard Law School, Finds and Fees Justice Center and Policy Advocacy Clinic at UC Berkeley School of Law. Accessed July 23, 2021. https://law.yale.edu/sites/default /files/area/center/liman/document/fees_fines _and_the_funding_of_public_services.pdf.

Hillsman, Sally T. 1988. "The Growing Challenge of Fine Administration to Court Managers." Justice System Journal 13(1): 5-16.

-1990. "Fines and Day Fines." Crime and Justice 12: 49-98.

Hillsman, Sally T., and Judith A. Greene. 1992. “The Use of Fines As an Intermediate Sanction." In Smart Sentencing: The Emergence of Intermediate Sanctions, edited by James M. Byrne, Art J. Lurigio, and Joan R. Petersilia. Newbury Park, Calif.: Sage.

Hillsman, Sally T., and Barry Mahoney. 1988. “Collecting and Enforcing Criminal Fines: A Review of Court Processes, Practices, and Problems." Justice System Journal 13(1): 17-36.

Kantorowicz-Reznichenko, Elena, and Michael Faure, eds. 2021. Day Fines in Europe: Assessing Income-Based Sanctions in Criminal Justice Systems. Cambridge: Cambridge University Press.

Katzenstein, Mary Fainsod, Nolan Bennett, and Jacob Swanson. 2020. "Alabama is U.S.: Concealed Fees in Jails and Prisons." UCLA Criminal Justice Law Review 4(1): 259-67.

Katzenstein, Mary Fainsod, and Maureen R. Waller. 2015. "Taxing the Poor: Incarceration, Poverty Governance, and the Seizure of Family Resources." Perspectives on Politics 13(3): 638-56.

Kirk, Gabriela, April Fernandes, and Brittany Friedman. 2020. "Who Pays for the Welfare State? Austerity Politics and the Origin of Pay-to-Stay Fees as Revenue Generation." Sociological Perspectives 63(6): 921-38.

Kohler-Hausmann, Issa. 2018. Misdemeanorland: Criminal Courts and Social Control in an Age of Broken Windows Policing. Princeton, N.J.: Princeton University Press.

Link, Nathan W. 2019. “Criminal Justice Debt During the Prisoner Reintegration Process: Who Has It and How Much?" Criminal Justice and Behavior 46(1): 154-72.

Link, Nathan W., Kathleen Powell, Jordan M. Hyatt, and Ebony L. Ruhland. 2021. "Considering the Process of Debt Collection in Community Corrections: The Case of the Monetary Compliance Unit." Journal of Contemporary Criminal Justice 37(1): 128-47.

Mai, Chris, and Maria Katarina E. Rafael. 2020. “User Funded? Using Budgets to Examine the 
Scope and Revenue Impact of Fines and Fees in the Criminal Justice System." Sociological Perspectives 63(6): 1002-14.

Maroto, Michelle, and Bryan L. Sykes. 2020. “The Varying Effects of Incarceration, Conviction, and Arrest on Wealth Outcomes Among Young Adults." Social Problems 67(4): 698-718.

Martin, Karin D. 2020. "'The Plurality of Perspectives on Monetary Sanctions': An Introductory Essay." Sociological Perspectives 63(6): 901-20.

Martin, Karin D., Sarah K.S. Shannon, Bryan L. Sykes, Frank Edwards, and Alexes Harris. 2018. “Monetary Sanctions: Legal Financial Obligations in the Criminal Justice System." Annual Review of Criminology 1(1): 471-91.

Martin, Karin D., Kimberly Spencer-Suarez, and Gabriela Kirk. 2022. “Pay or Display: Monetary Sanctions and the Performance of Accountability and Procedural Integrity in New York and Illinois Courts." RSF: The Russell Sage Foundation Journal of the Social Sciences 8(1): 128-47. DOI: https://doi.org/10.7758/RSF.2022.8.1.06.

McDonald, Douglas C., Judith Greene, and Charles Worzella. 1992. "Day Fines in American Courts: The Staten Island and Milwaukee Experiment." Washington: U.S. Department of Justice, Office of Justice Programs, National Institute of Justice. Accessed July 23, 2021. https://www.ojp.gov /pdffiles1/Digitization/136611NCJRS.pdf.

Middlemass, Keesha. 2017. Convicted and Condemned: The Politics and Policies of Prisoner Reentry. New York: New York University Press.

Morse, Michael. 2021. “The Future of Felon Disenfranchisement Reform: Evidence from the Campaign to Restore Voting Rights in Florida." California Law Review 109(3): 1143-97.

Mullaney, Fahy G. 1988. "Economic Sanctions in Community Corrections." Washington: U.S. Department of Justice, National Institute of Corrections. Accessed July 23, 2021. https://www.ojp .gov/pdffiles1/Digitization/115323NCJRS.pdf.

Natapoff, Alexandra. 2018. Punishment Without Crime: How Our Massive Misdemeanor System Traps the Innocent and Makes America More Unequal. New York: Basic Books.

Needham, Taylor, Abena Subira Mackall, and Becky Pettit. 2020. "Making Sense of Misdemeanors: Fine Only Offenses in Convivial Court Rooms." Sociological Perspectives 63(6): 962-77.

Nichol, Gene. 2020. “Forcing Judges to Criminalize
Poverty in North Carolina." UCLA Criminal Justice Law Review 4(1): 227-34.

O'Neill, Kate K., Ian Kennedy, and Alexes Harris. Forthcoming. “Debtor's Blocks: “How Monetary Sanctions Make Between-Neighborhood, Racial, and Economic Inequalities Worse." Sociology of Race and Ethnicity.

O'Neill, Kate K., Tyler Smith, and Ian Kennedy. 2022. "County Dependence on Monetary Sanctions: Implications for Women's Incarceration." RSF: The Russell Sage Foundation Journal of the Social Sciences 8(2): 157-72. DOI: https://doi.org /10.7758/RSF.2022.8.2.08.

O'Neil, Meghan, and Daniel Strellman. 2020. “The Hidden Cost of the Disease: Fines, Fees, and Costs Assessed on Persons with Alleged Substance Use Disorder." UCLA Criminal Justice Law Review 4(1): 235-46.

Pacewicz, Josh, and John N. Robinson III. 2020. “Pocketbook Policing: How Race Shapes Municipal Reliance on Punitive Fines and Fees in the Chicago Suburbs." Socio-Economic Review 19(3): 975-1003.

Page, Josh A., and Joe Soss. 2017. “Criminal Justice Predation and Neoliberal Governance." In Rethinking Neoliberalism: Resisting the Disciplinary Regime, edited by Sanford F. Schram and Marianna Pavlovskaya. New York: Routledge.

Page, Josh A., Victoria Piehowski, and Joe Soss. 2019. "A Debt of Care: Commercial Bail and the Gendered Logic of Criminal Justice Predation." RSF: The Russell Sage Foundation Journal of the Social Sciences 5(1): 150-72. DOI: https://doi .org/10.7758/RSF.2019.5.1.07.

Paik, Leslie. 2020. "Reflection on the Rhetoric and Realities of Restitution." UCLA Criminal Justice Law Review 4(1): 247-58.

Paik, Leslie, and Alexes Harris. 2015. "Court Ethnographies." In The Routledge Handbook of Qualitative Criminology, edited by Heith Copes and J. Mitchell Miller. New York: Routledge.

Paik, Leslie, and Chiara Packard. 2019. "Impact of Juvenile Justice Fines and Fees on Family Life: Case Study in Dan County, WI." Accessed July 23, 2021. https://debtorsprison.jlc.org/docu ments/jlc-debtors-prison-dane-county.pdf.

Pattillo, Mary, and Gabriella Kirk. 2020. “Pay Unto Caesar: Breaches of Justice in the Monetary Sanctions Regime." UCLA Criminal Justice Law Review 4(1): 49-77. 
—. 2021. “Layaway Freedom: Coercive Financialization in the Criminal Justice System." American Journal of Sociology 126(4): 889-930.

Pearlin, Leonard I. 1989. “The Sociological Study of Stress." Journal of Health and Social Behavior 30(3): 241-56.

Piquero, Alex, and Wesley Jennings. 2017. "Research Note: Justice System-Imposed Financial Penalties Increase the Likelihood of Recidivism in a Sample of Adolescent Offenders." In The Routledge Handbook of Qualitative Criminology, edited by Heith Lopes and J. Mitchell Miller. New York: Routledge.

Pleggenkuhle, Breanne. 2018. “The Financial Cost of a Criminal Conviction: Context and Consequences." Criminal Justice and Behavior 45(1): 121-45.

Rabinowitz, Mikaela, Robert Weisberg, and Lauren McQueen Pearce. 2019. “The California Criminal Justice Data Gap." Stanford, Calif.: Stanford Criminal Justice Center. Accessed July 23, 2021. https://www-cdn.law.stanford.edu/wp-content /uploads/2019/04/SCJC-DatagapReport_v07 .pdf.

Raher, Stephen. 2020. “The Company Store and the Literally Captive Market: Consumer Law in Prisons and Jails" Hastings Race \& Poverty Law Journal 17(1): 3-86.

Reynolds, Carl, and Jeff Hall. 2012 "Courts Are Not Revenue Centers." Williamsburg, Va.: Conference of State Court Administrators. Accessed July 23, 2021. https://cosca.ncsc.org/_data/assets/pdf _file/0019/23446/courtsarenotrevenuecenters -final.pdf.

Rhode Island Family Life Center. 2008. “Court Debt and Related Incarceration in Rhode Island from 2005 through 2007." Providence, R.I.: Rhode Island Family Life Center. Accessed July 23, 2021. http://www.opendoorsri.org/sites/default/files /CourtDebt.pdf.

Rosenthal, Alan, and Marsha Weissman. 2007. Sentencing for Dollars: The Financial Consequences of a Criminal Conviction. Syracuse, N.Y.: Center for Community Alternatives, Justice Strategies.

Ruback, Barry, and Mark Bergstrom. 2006. “Economic Sanctions in Criminal Justice: Purposes, Effects, and Implications." Criminal Justice and Behavior 33(2): 242-73.

Ruback, Barry R., Jennifer N. Shaffer, and Melissa A. Logue. 2004. "The Imposition and Effects of Res- titution in Four Pennsylvania Counties: Effects of Size of County and Specialized Collection Units." Crime and Delinquency 50(2): 168-88.

Ruback, Barry R., Stacy N. Hoskins, Alison C. Cares, and Ben Feldmeyer. 2006. "Perception and Payment of Economic Sanctions: A Survey of Offenders." Federal Probation 73: 26-31.

Ruhland, Ebony, Bryan Holmes, and Amber Petkus. 2020. "The Role of Fines and Fees on Probation Outcomes." Criminal Justice and Behavior 47(10): 1244-63.

Sances, Michael W., and Hye Young You. 2017. "Who Pays for Government? Descriptive Representation and Exploitative Revenue Sources." Journal of Politics 79(3): 1090-94.

Sanchez, Amairini, Michele Cadigan, Dayo AbelsSullivan, and Bryan L. Sykes. 2022. “Punishing Immigrants: The Consequences of Monetary Sanctions in the Crimmigration System." RSF: The Russell Sage Foundation Journal of the Social Sciences 8(2): 76-97. DOI: https://doi.org/10 .7758/RSF.2022.8.2.04.

Scott-Hayward, Christine S., and Henry F. Fradella. 2019. Punishing Poverty: How Bail and Pretrial Dentention Fuel Inequalities in the Criminal Justice System. Berkeley: University of California Press.

Seawright, Jason. 2016. Multi-Method Social Science: Combining Qualitative and Quantitative Tools. New York: Cambridge University Press.

Sebastian, Thea, Danielle Lang and Caren E. Short. 2020. "Democracy, If You Can Afford It: How Financial Conditions Are Undermining the Right to Vote." UCLA Criminal Justice Law Review 4(1): 79-116.

Shannon, Sarah K.S. 2020. "Probation and Monetary Sanctions in Georgia: Evidence from a MultiMethod Study." Georgia Law Review 54(4): 127596.

Shannon, Sarah K.S., Beth M. Huebner, Alexes Harris, Karin Martin, Mary Pattillo, Becky Pettit, Bryan Sykes, and Christopher Uggen. 2020. “The Broad Scope and Variation of Monetary Sanctions: Evidence from Eight States." UCLA Criminal Justice Law Review 4(1): 269-81.

Shapiro, Joseph. 2014. "As Court Fees Rise, the Poor Are Paying the Price." All Things Considered, May 19, 2014. Accessed July 23, 2021. https://www .npr.org/2014/05/19/312158516/increasing -court-fees-punish-the-poor. 
Slavinski, Ilya, and Becky Pettit. 2021. “Proliferation of Punishment: The Centrality of Legal Fines and Fees in the Landscape of Contemporary Penology." Social Problems. spaa077, https://doi.org /10.10.1093/socpro/spaa077.

Smith, Tyler, Kristina J. Thompson, and Michele Cadigan. 2022. "Sensemaking in the Legal System: A Comparative Case Study of Changes to Monetary Sanction Laws." RSF: The Russell Sage Foundation Journal of the Social Sciences 8(1): 68-81. DOI: https://doi.org/10.7758/RSF.2022 8.2.03.

Stewart, Robert, Brieanna Watters, Veronica Horowitz, Ryan P. Larson, and Christopher Uggen. 2022. "Native Americans and Monetary Sanctions." RSF: The Russell Sage Foundation Journal of the Social Sciences 8(2): 137-56. DOI: https:// doi.org/10.7758/RSF.2022.8.2.07.

Sykes, Bryan L., and Michelle Maroto. 2016. “A Wealth of Inequalities: Mass Incarceration, Employment, and Racial Disparities in U.S. Household Wealth, 1996-2011." RSF: The Russell Sage Foundation Journal of the Social Sciences 2(6): 129-52. DOI: https://doi.org/10.7758/RSF .2016.2.6.07.

Sykes, Bryan L., Meghan Ballard, Andrea Giuffre, Rebecca Goodsell, Daniela Kaiser, Vicente Celestino Mata, and Justin Sola. 2022. “Robbing Peter to Pay Paul: Public Assistance, Monetary Sanctions, and Financial Double-Dealings in America." RSF: The Russell Sage Foundation Journal of the Social Sciences 8(1): 148-78. DOI: https://doi .org/10.7758/RSF.2022.8.1.07.

Tonry, Michael, and Mary Lynch. 1996. "Intermediate Sanctions." Crime and Justice 20: 99-144.

Tran-Leung, Marie Claire. 2010. "Assessing the Ad Hoc Nature of Financial Obligations Arising in the Illinois Criminal Justice System." Journal of Poverty Law and Policy 43(9-10): 440-47. Ac- cessed July 23, 2021. http://research.policy archive.org/22092.pdf.

Turney, Kristin, and Sara Wakefield. 2019. "Criminal Justice Contact and Inequality." RSF: The Russell Sage Foundation Journal of the Social Sciences 5(1): 1-23. DOI: https://doi.org/10.7758/RSF 2019.5.1.01.

Uggen, Christopher, Ryan Larson, Sarah K.S. Shannon, and Arleth Pulido-Nava. 2020. "Locked Out 2020: Estimates of People Denied Voting Rights Due to a Felony Conviction." Washington, D.C: The Sentencing Project. Accessed July 23, 2021. https://www.sentencingproject.org/publications /locked-out-2020-estimates-of-people-denied -voting-rights-due-to-a-felony-conviction.

U.S. Commission on Civil Rights. 2017. “Targeted Fines and Fees Against Communities of Color: Civil Rights and Constitutional Implications." Washington: USCCR. Accessed July 23, 2021. https://www.usccr.gov/pubs/2017/Statutory _Enforcement_Report2017.pdf.

U.S. Department of Justice. 2015. "Investigation of the Ferguson Police Department." Washington: U.S. Department of Justice, Civil Rights Division. Accessed July 23, 2021. https://www.justice.gov /sites/default/files/opa/press-releases/attach ments/2015/03/04/ferguson_police_department _report.pdf.

Verma, Anjuli, and Bryan L. Sykes. 2022. “Beyond the Penal Code: The Legal Capacity of Monetary Sanctions in the Corpus of California Law." RSF: The Russell Sage Foundation Journal of the Social Sciences 8(2): 36-62. DOI: https://doi.org/10 .7758/RSF.2022.8.2.02.

Wacquant, Loïc. 2001. “Deadly Symbiosis: When Ghetto and Prison Meet and Mesh." Punishment and Society 3(1): 95-133.

Western, Bruce. 2018. Homeward: Life in the Year After Prison. New York: Russell Sage Foundation. 